\title{
THE LIMITS OF COPYRIGHT OFFICE EXPERTISE
}

\author{
Aaron Perzanowskit
}

\begin{abstract}
The mismatch between the expanding administrative and regulatory obligations of the United States Copyright Office and its limited institutional expertise is an emerging problem for the copyright system. The Office's chief responsibility—registration and recordation of copyright claims - has taken a back seat in recent years to a more ambitious set of substantive rulemakings and policy recommendations. As the triennial rulemaking under the Digital Millennium Copyright Act highlights, the Office is frequently called upon to answer technological questions far beyond its plausible claims of subject matter expertise. This Article traces the Office's history, identifies its substantial but discrete areas of expertise, and reveals the ways in which the Office has overstepped any reasonable definition of its expert knowledge. This Article concludes with a set of recommendations to better align the Office's agenda with its expertise by, first, reducing the current regulatory burdens on the Office, and second, building greater technological and economic competence within the Office, better equipping it to address contemporary questions of copyright policy.
\end{abstract}

DOI: https://doi.org/10.15779/Z38348GG7J

(C) 2018 Aaron Perzanowski.

† Professor of Law at Case Western Reserve University. I would like to thank Jonathan Band, Annemarie Bridy, Andy Gass, Corynne McSherry, Sasha Moss, Blake Reid, Mitch Stoltz, and Fred von Lohmann for their thoughtful comments and suggestions. 


\section{TABLE OF CONTENTS}

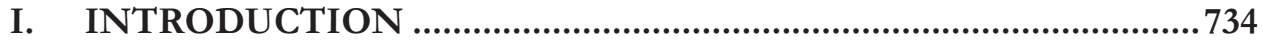

II. THE COPYRIGHT OFFICE .......................................................... 736

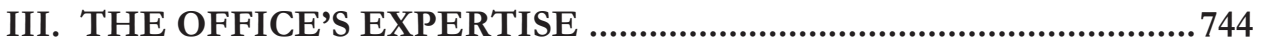

A. SubSTANTIVE REQUIREMENTS FOR REGISTRATION ..................................746

B. FORMAL REQUIREMENTS FOR REGISTRATION...........................................749

C. ADMINISTRATION OF STATUTORY LICENSES .............................................751

IV. THE LIMITS OF THE OFFICE'S EXPERTISE .............................754

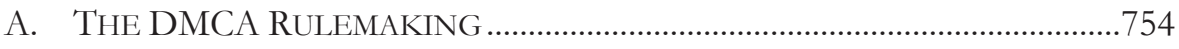

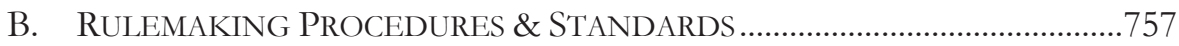

C. RULEMAKING SUBJECT MATTER \& EXPERTISE .............................................761

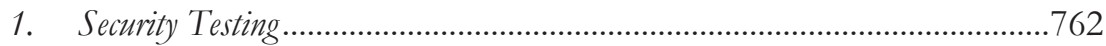

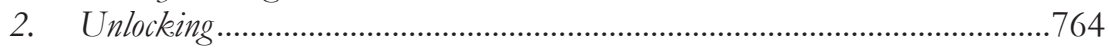

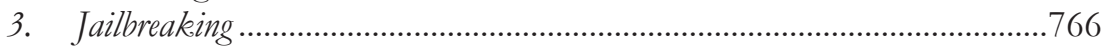

4. Additional 2015 Exemptions....................................................................766

V. AN EXPERT COPYRIGHT OFFICE ...........................................770

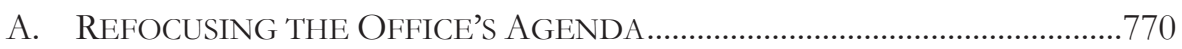

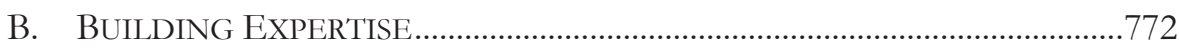

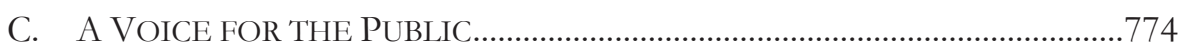

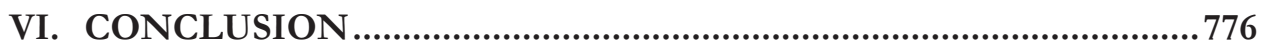

\section{INTRODUCTION}

Designed to serve the crucial yet prosaic function of registering copyright claims, the United States Copyright Office ("Office") increasingly asserts wideranging authority to interpret copyright law, advise courts and federal agencies, promulgate administrative and substantive rules, and broadly shape copyright policy. ${ }^{1}$ Recent years have witnessed a flurry of Office rulemaking and policy studies addressing issues from bulk registration ${ }^{2}$ and the location of copyright

1. See Letter from Karyn Temple Claggett, Acting Register of Copyrights, to David Levi, President, Am. Law Institute (Jan. 16, 2018), https://drive.google.com/file/d/ 1gAYHgxkUqre7LdRpIu4cEdBDJ3thdfpu/view [https://perma.cc/W9KN-PU32].

2. See Group Registration of Newspapers, 83 Fed. Reg. 4,144 (Jan. 30, 2018) (codified at 37 C.F.R. pts. 201, 202); Group Registration of Photographs, 83 Fed. Reg. 2,542 (Jan. 18, 2018) (codified at 37 C.F.R. pts. 201, 202). 
notices ${ }^{3}$ to resale royalties ${ }^{4}$ and orphan works. ${ }^{5}$ More controversially, the Office is in the midst of its seventh triennial rulemaking under $\int 1201$ of the Digital Millennium Copyright Act (DMCA) ${ }^{6}$ and has waded into, among other topics, copyright's application to software-enabled consumer devices like cars, kitchen appliances, and medical devices. ${ }^{7}$ Should security researchers be required to disclose the flaws they uncover to device makers and developers before going public? Should farmers be able to repair their tractors over the objections of manufacturers? These are the sorts of bizarrely incongruous questions that the Office confronts today.

At the same time, the Office faces nagging constitutional questions about the scope of its authority and an often contentious relationship with the Library of Congress, of which it remains a subordinate office. Motivated in part by these concerns, some have called for greater independence for the Office. These proposals are closely linked to ongoing efforts to concentrate additional authority within the Office. To take a recent example, the Copyright Alternative in Small-Claims Enforcement (CASE) Act would establish a small claims tribunal within the Office that has the power to adjudicate infringement disputes. ${ }^{8}$

As the federal body responsible for administering copyright law, the Office offers considerable expertise on questions at the core of its competence. However, as a result of both Congressional mandates and the Office's own ambitions, mission creep poses a problem. The Office regularly tackles complex economic and technological questions that extend well beyond both its historical mission and its most credible claims of subject matter expertise. Mission creep is a cause for concern for at least two reasons. First, through both the input it provides to Congress and its own direct regulatory action, the Office may advocate or adopt flawed policies. Second, the Office's growing

3. See Affixation and Position of Copyright Notice, 82 Fed. Reg. 42,735 (Sept. 12, 2017) (codified at 37 C.F.R. pts. 201, 202).

4. See U.S. Copyright Office, Resale Royalties: An Updated Analysis (2013).

5. See U.S. Copyright OfFice, Orphan Works and Mass Digitization (2015).

6. See 17 U.S.C. S 1201(a)(1)(C) (providing for a rulemaking conducted by the Librarian of Congress, acting on the recommendation of the Register of Copyrights, to determine whether "users of a copyrighted work are, or are likely to be in the succeeding 3-year period, adversely affected by $[\$$ 1201(a)(1)(A)] in their ability to make noninfringing uses under this title of a particular class of copyrighted works").

7. See U.S. Copyright Office, Software-Enabled Consumer Products (2016) [hereinafter CONSUMER PRODUCTS REPORT].

8. See H.R. 5757, 114 ${ }^{\text {th }}$ Cong. (2d Sess. 2016), H.R. 3945, 115th Cong. (1st Sess. 2017). See generally Ben Depoorter, If You Build It, They Will Come: The Promises and Pitfalls of a Copyright Small Claims Process, 33 Berkeley TeCH. L.J. 711 (2018); Pamela Samuelson \& Kathryn Hashimoto, Scholarly Concerns About a Proposed Small Copyright Claims Tribunal, 33 BERKELEY TECH. L.J. 689 (2018). 
docket distracts it from its core task of developing and maintaining a registration system that serves the needs of copyright holders and the public.

In some ways, the strains facing the Office are an unavoidable byproduct of an environment that is profoundly shaped by technological change and the expanding scope and significance of copyright law. Software copyright, technological protection measures, and digital distribution have altered the copyright landscape in dramatic ways. ${ }^{9}$ Copyright law now regulates the use of software, both directly and indirectly, that is embedded in an astounding range of every day devices, even in the absence of traditional copyright infringement. ${ }^{10}$ The need for experts to inform copyright policy in light of these developments is evident. Copyright law today implicates matters of security, privacy, and industrial competition that were entirely foreign to copyright policy debates just a few decades ago. But delegations and assertions of authority are insufficient to establish genuine expertise. If the Office intends to lead the policy conversation moving forward, it needs to build competence in those areas in which it is currently lacking. That process should begin with a frank assessment of the questions the Office is well-positioned to answer and those it is not.

This Article, while far from comprehensive, contributes to that conversation. Part II situates the Office, both historically and constitutionally, and considers recent proposals to alter its structure. Part III considers the role of expertise in justifying agency authority generally before turning to the core competencies of the Office. Part IV identifies the limits of the Office's expertise and focuses on perhaps the clearest example of the Office operating beyond its expertise, the triennial DMCA rulemaking. Part V considers how the Office might build the expertise necessary for a twenty-first century copyright agency.

\section{THE COPYRIGHT OFFICE}

The Office owes its origin to the system of formalities-now largely vestigial - that defined U.S. copyright law for centuries. The Copyright Act of 1790 required works to be registered with federal district courts and copies to be deposited with the Secretary of State. ${ }^{11}$ The 1870 overhaul of the Copyright

9. More broadly, copyright law is not alone in facing new regulatory challenges in the face of ubiquitous software. See Paul Ohm \& Blake Reid, Regulating Software When Everything Has Software, 84 GEO. WASH. L. REV. 1672, 1673 (2016) (describing this trend as "the inevitable result of embedding software in everything").

10. But see Chamberlain Group, Inc. v. Skylink Techs., Inc., 381 F.3d 1178 (Fed. Cir. 2004) (holding that a claim for circumvention requires a "critical nexus" to copyright infringement).

11. Copyright Act of 1790, 1 Stat. 124 SS 3, 4. 
Act, championed by Librarian of Congress's Ainsworth Spofford, centralized registration and deposit within the Library, simultaneously bolstering its holdings and increasing copyright registrations. ${ }^{12}$ Spofford also created a Copyright Department within the Library to administer its new responsibilities. ${ }^{13}$ The first Register of Copyrights, Thorvald Solberg, was named in 1897 and served for 33 years. ${ }^{14}$

Since its inception, the bulk of the Office's duties have been administrative. ${ }^{15}$ It reviews registration applications; it receives deposit copies; it records facts related to registrations and assignments; it collects and disburses royalties under compulsory licenses. ${ }^{16}$ This work is crucial to a functioning copyright system. In particular, an accurate record of copyrighted works and their corresponding rights holders benefits authors, publishers, licensees, and the public more generally. ${ }^{17}$ Such a record allows the public to reliably determine whether a work is protected in the first place. It also facilitates transactions, making sure creators can be paid for their work. ${ }^{18}$ Moreover, it provides opportunities for researching the copyright system and its effects on creative production.

In addition to its primary administrative duties, the Office took an active role in copyright policy early in its history. Befitting an arm of the Library of Congress, the Office has consistently weighed in on legislative amendments to the Copyright Act. Beginning in 1901, Solberg authored a series of annual reports calling on Congress to revise the Act. ${ }^{19}$ In the lead up to what became the Copyright Act of 1909, the Office organized a series of stakeholder conferences to discuss reform proposals and produced a draft bill. ${ }^{20}$ At the

12. See William F. Patry, 7 Patry on Copyright \ 26:1 (2018) [hereinafter 7 Patry ON COPYRIGHT].

13. See id.

14. See id.

15. See Maria A. Pallante, The Next Great Copyright Act, 36 ColuM. J.L. \& ARTs 315, 341 (2013) ("In fact, from 1897 to 1998, the role was largely, though not entirely, administrative, meaning most regulations addressed administrative questions, i.e., rules pertaining to the registration process, the collection of fees, and the administration of certain aspects of compulsory licenses.").

16. U.S. Copyright Office, A Brief Introduction and History, https://www.copyright.gov/ circs/circ1a.html [https://perma.cc/DX58-5AMW] (last visited Nov. 19, 2018).

17. See Maria A. Pallante, The Next Generation Copyright Office: What It Means and Why It Matters, 61 J. COPYRIGHT SOC’Y U.S.A. 213, 228-29 (2014). (2005).

18. See James Gibson, Once and Future Copyright, 81 Notre DAME L. REV. 167, 227-28

19. See Librarian of Congress, Report of the Librarian OF CONGRESS FOR the FisCAL YEAR ENDING JUNE 30, 1901 at 11 (1901); 7 PATRY ON COPYRIGHT, supra note 12, at $\int 26: 2$.

20. Zvi S. Rosen, The (First) Register of Copyrights and the Drafting of the 1909 Copyright Act, MOSTLY IP History (May 12, 2017), http://www.zvirosen.com/2017/05/12/the-first- 
request of Congress, the Office prepared dozens of influential studies of substantive legal questions during the decades-long process that culminated in the Copyright Act of 1976. ${ }^{21}$ The Office has also been involved in debates over international copyright treaties since the early twentieth century. ${ }^{22}$

The current statute outlines the responsibilities of the Office with some specificity. In addition to performing "all administrative functions and duties" 23 required to implement the Act-and creating regulations necessary to do the same ${ }^{24}$ - the Office is to advise Congress, inform and assist federal agencies and the judiciary, engage with foreign governments and intergovernmental organizations, and conduct studies related to copyright law..$^{25}$ As discussed below, these duties have been supplemented by legislation empowering the Office to engage in specific rulemaking.

Given this mix of duties, the Office is a rather curious creature within our constitutional system. On the one hand, because it is housed within the Library of Congress, the Office would appear, as a structural matter, squarely within the legislative branch. ${ }^{26}$ The frequent research and policy input that Congress requires from the Office bolster that view. On the other hand, the Office's administrative functions-promulgating rules and administering aspects of a complex federal statute-are more consistent with an executive agency. In addition, the Librarian, who oversees the Register and the Office, is a presidential appointee. ${ }^{27}$

register-of-copyrights-and-the-drafting-of-the-1909-copyright-act/

[https://perma.cc/ RY2E-GH6D].

21. See U.S. Copyright OfFice, Copyright LAW REvision STUdies, https://www.copyright.gov/history/studies.html [https://perma.cc/Q3M8-UJB8]; see 7 PATRY ON COPYRIGHT, supra note 12 , at \26:3.

22. See 7 PATRY ON COPYRIGHT, supra note 12 , at $\$ 26: 2$.

23. 17 U.S.C. $\int 701$ (a) (2012).

24. See 17 U.S.C. $\int 702$.

25. See 17 U.S.C. $\int 701(\mathrm{~b})$.

26. See 5 U.S.C. $\int 5531$ (4) (defining the Library of Congress, along with the Government Accountability Office, the Government Publishing Office, the Office of Technology Assessment, the Office of the Architect of the Capitol, the United States Botanic Garden, the Congressional Budget Office, and the United States Capitol Police as an "agency in the legislative branch").

27. See 2 U.S.C. $\int 136-1$ ("The President shall appoint the Librarian of Congress, by and with the advice and consent of the Senate.’). 
When it comes to deciding in which branch of the federal government the Office belongs, the courts are split. ${ }^{28}$ Likewise, both members of Congress ${ }^{29}$ and the executive branch $^{30}$ have expressed consternation over the question. President Clinton went so far as to issue a signing statement accompanying the DMCA, which vested the Office with new substantive rulemaking responsibilities, declaring that "for constitutional purposes" the Office is an "executive branch entity." And while the Office proclaims itself a part of the legislative branch, ${ }^{32}$ it frequently acts as if it were an executive agency and

28. Some courts have concluded that the Office is part of the legislative branch. See, e.g., United States v. Brooks, 945 F. Supp. 830, 834 (E.D. Pa. 1996) (“[T]he Copyright Office is part of the legislative branch.”); Harry Fox Agency, Inc. v. Mills Music, Inc., 720 F.2d 733, 736 (2d Cir. 1983) ("[T] Le Library of Congress ... is a part of the legislative branch itself....”); Barger v. Mumford, 265 F.2d 380, 382 (D.C. Cir. 1959) (“[T]he Library of Congress has long been treated as being in or under the jurisdiction of the legislative branch ...."). Other courts have deemed the Office executive in nature. See, e.g., Eltra Corp. v. Ringer, 579 F.2d 294, 301 (4th Cir. 1978) ("[T]he Copyright Office is an executive office ....”); Intercollegiate Broad. Sys., Inc. v. Copyright Royalty Bd., 684 F.3d 1332, 1342 (D.C. Cir. 2012) (discussing why the Library of Congress "is undoubtedly a "component of the Executive Branch" "). Acknowledging that "it is not clear whether the Library of Congress is part of the executive or legislative branch," the Ninth Circuit explicitly avoided the question in Fox Television Stations, Inc. v. Aereokiller, LLC, 851 F.3d 1002, 1013 n.4 (9th Cir. 2017) (noting that if it were to decide what level of deference the Office is owed, the court "would be required to rule on constitutional questions that could have outsized consequences relative to this case-such as determining whether the Library of Congress is a legislative or executive agency").

29. Senator Orin Hatch, for example, has maintained that "the Copyright Office is in the legislative branch of the Government, [and] whenever [it] is tasked with an executive-type function, [a] constitutional question arises." See John Duffy, Peter Strauss \& Michael Herz, Copyright's Constitutional Chameleon, CONCURRING OpINIONS (May 17, 2013), https://concurringopinions.com/archives/2013/05/copyrights-constitutional-chameleon .html\#more-74811 [https://perma.cc/NU7E-UUCQ]; see also H.R. REP. No. 105-796, at 77 (1998) (Conf. Rep.) (referring to the Office as "a hybrid entity that historically has performed both legislative and executive or administrative functions" and as "a legislative branch agency").

30. A 1996 Office of Legal Counsel memo cautioned that entities such as the Library of Congress, "exercise authority that seems incompatible or at least difficult to reconcile with the Supreme Court's anti-aggrandizement decisions." Constitutional Separation of Powers Between the President and Cong., 20 Op. O.L.C. 124, 172 (1996).

31. Presidential Statement on Signing the Digital Millennium Copyright Act, 2 PuB. PAPERS 1902 (Oct. 28, 1998) ("I am advised by the Department of Justice that certain provisions of H.R. 2281 and the accompanying Conference Report regarding the Register of Copyrights raise serious constitutional concerns. Contrary to assertions in the Conference Report, the Copyright Office is, for constitutional purposes, an executive branch entity.").

32. See U.S. Copyright Office, supra note 16 ("As a service unit of the Library of Congress, the Copyright Office is part of the legislative branch of government."). In remarks addressing constitutional challenges to copyright law, then-Register Marybeth Peters explained that "being in the legislative branch, my office is institutionally disinclined to take kindly to 
accepts that characterization when it is expedient. ${ }^{33}$

This ambiguity raises important constitutional questions. If the Office is an arm of Congress, its substantive rulemaking would appear to violate the separation of powers by subverting the processes for lawmaking set out in Article I. ${ }^{34}$ Perhaps not surprisingly, the Office's authority has been challenged on constitutional grounds. In Eltra Corporation v. Ringer, the plaintiff brought an action seeking to compel the Register of Copyrights to register its typeface design after the Office refused. ${ }^{35}$ Eltra maintained that the Office, as an arm of the legislature, lacked the power to refuse registration applications. ${ }^{36}$ Under Eltra's view, the Office's power is "very strictly limited to the receipt, deposit and issuance of a registration certificate." ${ }^{37}$ However, the Fourth Circuit rejected that argument, focusing instead on the Office's longstanding practices of issuing rules and regulations. ${ }^{38}$

Notably, Eltra was decided before two important Supreme Court separation of powers cases. These cases embrace a formal rather than functional approach to situating entities like the Office within the legislative or executive branches, and potentially undermine Eltra's analysis. ${ }^{39}$ Thus,

challenges to the constitutionality of copyright legislation." Marybeth Peters, Constitutional Challenges to Copyright Law, 30 COLUM. J.L. \& ARTS 509, 509 (2007). The Librarian of Congress has offered similar characterizations. See Duffy et al., supra note 29 (noting that the "Librarian has repeatedly testified to Congress that the Library is 'arm of the United States Congress,' a 'branch of the Legislative branch,' and 'a unique part of the Legislative Branch of the government' ").

33. See, e.g., Eltra Corp. v. Ringer, 579 F.2d 294 (4th Cir. 1978). The Copyright Royalty Board has faced its own constitutional challenges. See Live365, Inc. v. Copyright Royalty Bd., 698 F. Supp. 2d 25 (2010); Intercollegiate Broad. Sys., Inc. v. Copyright Royalty Bd., 684 F.3d 1332, 1334 (D.C. Cir. 2012) ("[W]e agree with Intercollegiate that the position of the CRJs, as currently constituted, violates the Appointments Clause ....”). The Department of Justice, on behalf of the Library of Congress, has argued in the context of a CRB dispute that the Library is an executive department for Appointments Clause purposes. See Brief for the Federal Respondents in Opposition at 16, Intercollegiate Broad. Sys., Inc. v. Copyright Royalty Bd., 684 F.3d 1332 (D.C. Cir. 2010) (No. 12-928), 2013 WL 1792498, at *15.

34. Metro. Wash. Airports Auth. v. Citizens for Abatement of Aircraft Noise, 501 U.S. 252, 276 (1991) ("If the power is executive, the Constitution does not permit an agent of Congress to exercise it. If the power is legislative, Congress must exercise it in conformity with the bicameralism and presentment requirements of Art. I, $\left.\int 7 . ”\right)$. For a thorough discussion of the constitutional issues surrounding the Office's rulemaking authority, see Andy Gass, Considering Copyright Rulemaking: The Constitutional Question, 27 BERKELEY TECH. L.J. 1047 (2012).

35. See Eltra Corp., 579 F.2d at 296.

36. See id. at 301.

37. Id. at 298.

38. See id. at 298-299.

39. See Bowsher v. Synar, 478 U.S. 714 (1986); Metro. Wash. Airports, 501 U.S. at 269 (1991); see also Gass, supra note 34, at 1053-56. 
questions about the extent of the Office's constitutional authority linger. More recently, when the Office recommended and the Librarian approved an exemption under the DMCA that permitted the unlocking of mobile phones, Tracfone filed a challenge to the rulemaking, arguing that it represented either an intra-branch delegation of legislative authority or the exercise of executive power by the legislature. ${ }^{40}$ The constitutional question was left unsolved, however, because Tracfone dropped the suit after successfully suing phone unlockers despite the exemption. ${ }^{41}$

Concerns over the Office's constitutional authority have contributed to a number of proposals for its reorganization and the redistribution of its duties. A bill introduced in 2015 would have transformed the Office into an independent quasi-executive agency. ${ }^{42}$ And in 2017, the House passed a bill that stripped the Librarian of Congress of her power to name the next Register of Copyrights. ${ }^{43}$ Instead, the Register would be chosen by the President from a list of candidates generated by a congressional panel. ${ }^{44}$ Commentators have suggested some duties currently within the purview of the Office could be better carried out by the Departments of Justice or Commerce, the latter of which houses the U.S. Patent and Trademark Office. ${ }^{45}$ Others have raised the possibility of relocating the Office within Commerce or creating a new and independent IP agency. ${ }^{46}$ But the recent attention to the Office is motivated by more than an abstract concern over the separation of powers. Rather, changes in the leadership of both the Library and the Office are at least partly responsible.

In 2015, longtime Librarian of Congress James Billington, first appointed

40. Complaint at 2, Tracfone Wireless, Inc. v. Billington, No. 06-22942 (S.D. Fla. Dec. $5,2006)$.

41. See David Kravets, Ruling Allows Cell Phone Unlocking, but Telco Sues Anyway, WIRED (Aug. 8, 2007), https://www.wired.com/2007/08/tracfone [https://perma.cc/2CN5-79KE].

42. See Copyright Office for the Digital Economy Act, H.R. 4241, 114th Cong. (2015). (2017).

43. See Register of Copyrights Selection and Accountability Act, H.R. 1695, 115th Cong.

44. See id.

45. See Jarrett Dieterle \& Sasha Moss, Moving Copyright Office Authorities to Executive Branch Could Improve Accountability, HiLL (Mar. 28, 2017), http://thehill.com/blogs/punditsblog/lawmaker-news/326246-moving-copyright-office-authorities-to-executive-branch [https://perma.cc/XQ56-Z7RH] ("Internet-related procedural functions like notice-andtakedown and circumvention exemptions could be placed in the Commerce Department. Statutory licensing and rate-setting issues, such as through the Copyright Royalty Board, could be moved into the Department of Justice, which has substantial antitrust expertise.”).

46. See Sandra M. Aistars, The Next Great Copyright Act, or A New Great Copyright Agency?, 38 COLUM. J.L. \& ARTS 339, 346 (2015). The Omnibus Patent Act of 1996 would have created a government corporation uniting the functions of the Copyright Office and the USPTO. See Omnibus Patent Act of 1996, S. 1961, 104th Cong. (1996). 
by President Reagan, retired amid considerable controversy. ${ }^{47} \mathrm{~A}$ series of inspector general reports revealed a pattern of mismanagement within the Library. ${ }^{48}$ In particular, the Library's embrace of digital technology was woefully anemic. This inadequate technological infrastructure of the Library had a direct impact on the Office, ${ }^{49}$ fueling calls by the Register for greater independence. ${ }^{50}$

The Office, however, has dealt with its own missteps in recent years. After working for the better part of a decade to digitize pre-1978 registrations, the Office succeeded, at long last, in scanning its card catalog. But that catalog is not searchable, nor does it include registration records. ${ }^{51}$ And while new registration applications can be filed electronically, the Office continued to insist on paper records for registering DMCA agents until 2016. ${ }^{52}$ Furthermore, a recent Inspector General report found that the Office's ultimately abandoned Electronic Licensing System, originally budgeted at just over \$1 million, consumed almost $\$ 12$ million over six years-overruns that the Office failed to disclose to Congress. ${ }^{53}$

47. See Michael D. Shear, Library of Congress Chief Retires Under Fire, N.Y. TIMES (June 10, 2015), https://www.nytimes.com/2015/06/11/us/library-of-congress-chief-james-hadleybillington-leaving-after-nearly-3-decades.html [https://perma.cc/MA9Y-G976] (noting that Billington "presided over a series of management and technology failures at the library that were documented in more than a dozen reports by government watchdog agencies"); Peggy McGlone, Librarian's Trips Abroad, Posh Hotels All Paid for by James Madison Council, WASH. Post (Aug. 12, 2015), https://www.washingtonpost.com/entertainment/museums/jamesmadison-council-a-whos-who-of-philanthropists-and-titans/2015/08/12/a12f55c2-3f78-

11e5-9561-4b3dc93e3b9a_story.html?utm_term=.8f20c9b54d1e [https://perma.cc/Q7C3$5 \mathrm{FX} 5]$.

48. See, e.g., Library of Congress OfFice of the Inspector General, SEMIANNUAL REPORT TO THE CONGRESS 7 (Sept. 2015), https://www.loc.gov/portals/static /about/office-of-the-inspector-general/annual-reports/documents/september-2015-semi annual-report.pdf [https://perma.cc/7YS3-5FAZ] (noting "significant strategic and operational issues in the Library's information technology (IT) infrastructure and management" dating back to 2009).

49. See Peggy McGlone, Copyright Office's Online Registration Hasn't Worked for Almost a Week, WASH. POST (Sept. 3, 2015), https://www.washingtonpost.com/lifestyle/style/ copyright-offices-online-registration-hasnt-worked-for-almost-a-week/2015/09/03/

b12781e2-5261-11e5-9812-92d5948a40f8_story.html?utm_term=.f77d1ddd4bb3

[https://perma.cc/28PH-W3T4].

50. See U.S. Rep. Zoe Lofgren (D-Calif.), Statement in Opposition to H.R. 1695, https://lofgren.house.gov/sites/lofgren.house.gov/files/migrated/UploadedFiles/Dissentin g_Views_Markup_03-29-17_Copyright_Bill_Final.pdf [https://perma.cc/5TMA-P6LA].

51. See id.

52. See Designation of Agent to Receive Notification of Claimed Infringement, 81 Fed. Reg. 75,695 (Nov. 1, 2016) (codified at 37 C.F.R. pt. 201).

53. Library of CONGRESS OfFICE of THE INSPECTOR GENERAL, FY 16 REVIEW OF SYSTEMS DEVELOPMENT LIFECYCLE 8 (Feb. 2017). 
In 2016, both the Library and the Office underwent changes in leadership. That year, President Obama nominated Carla Hayden, former president of the American Library Association, as James Billington's successor as Librarian of Congress. ${ }^{54}$ As Librarian, Hayden has taken a more active role than her predecessor, particularly with respect to issues surrounding technology and information accessibility. ${ }^{55}$ And in October of 2017, Hayden reassigned thenRegister Pallante, who resigned in protest. ${ }^{56}$ In the wake of that news, speculation ran rampant that Google, long seen as hostile to the entertainment industry, was behind Hayden's decision. ${ }^{57}$

In some ways, blaming industry influence for the seemingly abrupt change of leadership within the Office is an understandable impulse. Industry connections have shaped Office staffing in the past. ${ }^{58}$ Pallante formerly served as the Executive Director of the National Writers Union and Assistant Director of the Authors Guild, ${ }^{59}$ and she was named President of the Association of American Publishers just weeks after leaving the Office. ${ }^{60}$ Similarly, the Office's current Acting Register formerly served as Vice President for Litigation and Legal Affairs at the Recording Industry

54. See Nicholas Fandos, Carla Hayden Nominated to Head Library of Congress, N.Y. TimeS (Feb. 24, 2016), https://www.nytimes.com/2016/02/25/us/carla-hayden-nominated-tohead-library-of-congress.html [https://perma.cc/G24W-WKG7].

55. See Carla Hayden, Librarian of Cong., Hearing on Fiscal Year 2017 Budgets for Legislative Branch Entities, Remarks Before the House Administration Committee (Feb. 6, 2017) (" $[\mathrm{H}]$ igh on my priority list is modernization of the Copyright Office. It must be accessible to its users; registration must be user-friendly; and a searchable database of copyright holders should be available. These improvements will make an enormous difference to this important segment of the American economy.").

56. See Resignation Letter from Maria Pallante, then-Register of Copyrights, to Carla Hayden, Librarian of Cong. (Oct. 24, 2016).

57. See Peggy McGlone, Songwriters Say This Federal Bureaucrat Championed Their Rights. Now She's Lost Her Job, WASH. POST (Nov. 7, 2016), https://www.washingtonpost.com/ entertainment/music/with-change-at-the-top-of-copyright-office-a-battle-brews-over-freecontent/2016/11/07/a8c0b140-a4ea-11e6-8042-f4d111c862d1_story.html?utm_term= .3091cfcb879f [https://perma.cc/7MQD-YGVQ]; A Copyright Coup in Washington, WaLl ST. J. (Nov. 2, 2016), https://www.wsj.com/articles/a-copyright-coup-in-washington1478127088 [https://perma.cc/QZ47-X5ZZ].

58. Meredith Rose, Ryan Clough \& Raza Panjwani, Captured: Systemic Bias AT THE U.S. COPYRIGHT OFFICE 4 (2016) ("The Office has a well-trodden revolving door between its leadership, its other legal and policy staff and major rightsholders and their representatives.").

59. See id. at 5.

60. See Press Release, Ass'n of Am. Publishers, The Association of American Publishers (AAP) Names Maria A. Pallante as President and CEO (Jan. 12, 2017), http:/ / newsroom.publishers.org/the-association-of-american-publishers-aap-names-maria-apallante-as-president-and-ceo/ [https://perma.cc/D65F-HLN6]. 
Association of America. ${ }^{61}$ So when a personnel change that copyright holders found objectionable occurred, it was perhaps natural for them to assume a larger, more powerful industry influence was to blame.

But there is a simpler explanation. A Register who neglects and mismanages the Office's core functions, while publicly advocating for independence from her immediate supervisor, may find herself in a precarious position under reinvigorated leadership. ${ }^{62}$

Given its recent upheaval, the lingering questions about the scope of its authority, and the related reorganization proposals, now is an opportune moment to take stock of the Office's expertise. As the next Part will demonstrate, the Office has earned the right to assert its expertise with respect to a number of questions at the heart of its regular administrative duties.

\section{THE OFFICE'S EXPERTISE}

One of the core justifications for granting agencies regulatory authority is expertise. ${ }^{63}$ An expert agency brings greater substantive knowledge, experience, and skill to bear on complex problems, giving the public confidence in its determinations. Both rulemaking authority and judicial deference to agency interpretations depend in large part on the assumption of agency expertise.

Despite its centrality in administrative law, expertise remains a poorly defined concept. ${ }^{64}$ Intuitively, we understand expertise as a function of

61. Rose, Clough \& Panjwani, supra note 58 , at 5.

62. See 7 PATRY ON COPYRIGHT, supra note 12, at $\int 26: 4$ (2018) (the problems identified in the 2017 Inspector General's report as well as "Pallante's continued lobbying for the Copyright Office to become an independent agency, may have led to her replacement by Librarian of Congress Carla Hayden"); Annemarie Bridy, Murder (or not) at the Library of Congress?, WASH. POST (Oct. 31, 2016), https://www.washingtonpost.com/news/volokhconspiracy/wp/2016/10/31/murder-or-not-at-the-library-of-congress/?utm_term= .b514e5bab48b [https://perma.cc/73HF-676S] (providing as "a simple and plausible explanation" for Pallante's removal her "fairly brazen" effort "to withdraw [the Office] from the [Library], of which it has been a part since 1897").

63. See Skidmore v. Swift \& Co., 323 U.S. 134, 139-40 (1944) (noting the administrator's "specialized experience and broader investigations and information" and concluding that its rulings and interpretations "constitute a body of experience and informed judgment to which courts and litigants may properly resort for guidance"); SEC v. Chenery Corp., 332 U.S. 194, 199, 201-07 (1947) (noting the Commission's “accumulated experience" enabled it to make "an informed, expert judgment on the problem"); Chevron, U.S.A., Inc. v. Nat. Res. Def. Council, Inc., 467 U.S. 837, 865 (1984) (suggesting that Congress deferred to the administrator because of its "great expertise" and noting that "judges are not experts in the field"); United States v. Mead Corp., 533 U.S. 218, 228 (2001) (identifying an agency's "relative expertness" as a factor in determining the appropriate degree of deference).

64. See Sidney A. Shapiro, The Failure to Understand Expertise in Administrative Law: The Problem and the Consequences, 50 WAKE FOREST L. REV. 1097, 1097 (2015) ("For a concept that 
repeated experience. ${ }^{65}$ But often the assumption seems to be that expertisewhatever it is - emerges from the delegation of authority to an agency. ${ }^{66} \mathrm{On}$ occasion, though, courts have recognized that an agency's general expertise within a field is no guarantee that expertise supports every exercise of its authority. ${ }^{67}$

In one of the few serious attempts to move beyond our intuitive notion of what it means to be an expert, Sidney Shapiro, a leading commentator on administrative procedure and regulatory policy, draws on the work of sociologists Harry Collins and Robert Evans to outline a number of distinct types of expertise. ${ }^{68}$ Two varieties of specialized expertise, contributory and interactional, are particularly useful in thinking about the scope and strength of an agency's claimed expertise. Contributory expertise "is the knowledge necessary to undertake an activity with the competence expected of those who are trained in a discipline." ${ }^{\prime 69}$ If you possess contributory expertise, you can meaningfully engage in a particular activity or practice. A chef, for example, has contributory expertise when it comes to creating and executing a recipe. In contrast, "interactional expertise is the mastery of the language of a specialized domain" that falls short of practical competence. ${ }^{70}$ So a food critic may have interactional expertise, even if she lacks the ability to prepare a gourmet meal. These specialized forms of expertise can be acquired through both formal education and experience. ${ }^{71}$ Administrative officials in particular, Shapiro argues, can develop expertise "in the assessment of conflicting evidence and arguments, disciplinary perspectives, political demands, and legal commands." 72

Consistent with this framework, the Office's claim to expertise is strongest

is so central to administrative law, there has been a surprisingly impoverished understanding of expertise and its role in the rulemaking process.").

65. See Richard B. Stewart, The Reformation of American Administrative Law, 88 HARV. L. REV. 1667, 1678 (1975) (describing expertise as "the knowledge that comes from specialized experience").

66. See, e.g., Douglas H. Ginsburg, Appellate Courts and Independent Experts, 60 CASE W. RES. L. REV. 303, 318 (2010) ("The agencies, of course, develop expertise in the field or the industry they are charged with regulating.").

67. See, e.g., De La Mota v. U.S. Dep't of Educ., 412 F.3d 71, 80 (2d Cir. 2005) (holding that the interpretation did not reflect agency expertise); Wilderness Soc'y v. U.S. Fish \& Wildlife Serv., 353 F.3d 1051, 1069 (9th Cir. 2003) (agency decision did not "reflect the product of specialized agency expertise"); Hall v. EPA, 273 F.3d 1146, 1156 (9th Cir. 2001) (holding that EPA's decision did not reflect expertise).

68. See Shapiro, supra note 64, at 1102-05.

69. Id. at 1103 .

70. Id. at 1104 .

71. Id. at $1104-05$.

72. Id. at 1105 . 
when it comes to questions that leverage its unique institutional knowledge and the insights generated by routinely confronting issues in the course of its administrative duties. ${ }^{73}$ For most of the Office's history, those duties have centered on its "ministerial functions, such as registration and deposit." 74 The Office's expertise, however, is not limited to administrative mechanics. Rather, registration entails meaningful substantive evaluation of a work. In addition, the Office is uniquely situated to administer and interpret certain aspects of the statutory licenses under its care, some of which it has managed for over a century. ${ }^{75}$

\section{A. SubStantive REQUiREMENTS FOR REgISTRATION}

The bulk of the Office's resources and, by extension, expertise are directed to copyright registration. ${ }^{76}$ Nearly half of Office staff work in the registration division. ${ }^{77}$ And in fiscal year 2016 alone, the Office received 533,606 registrations claims. ${ }^{78}$ Given that volume and the relatively low standards for

73. The Office has at times overestimated its role, envisioning itself as the primary, if not sole, interpreter of the text of the Copyright Act. For example, in suggesting the American Law Institute should "reconsider" the existence of its Restatement of Copyright Law, Acting Register Karyn Temple expressed the view that the blackletter law of copyright requires no further explanation and that, in any event, "[t]here can be no more accurate statement of the law than the words that Congress has enacted in the Copyright Act and those that the Copyright Office has adopted in its regulations." See Claggett, supra note 1. Aside from ignoring the crucial role of courts in interpreting the Act, this view wildly overstates the degree of clarity and consensus on core questions of copyrightability, infringement, exceptions, and limitations. It also reflects an inflated understanding of the Office's place in the copyright system.

74. Joseph P. Liu, Regulatory Copyright, 83 N.C. L. REV. 87, 148 (2004).

75. Even within the core of the Office's expertise, however, courts typically afford its determinations deference only to the extent they find them persuasive. See generally WILLIAM F. PAtry, 5 PAtry on COPyright \ 17:102 (2018) [hereinafter 5 PATRY ON COPYRight]; Melville B. Nimmer \& DAvid Nimmer, 2 Nimmer on Copyright $\int 7.26$ (2018) [hereinafter 2 NimMER ON COPYRIGHT].

76. As Joseph Liu points out in his contribution to this volume, $28 \%$ of the Office's regulations relate directly to registration. See Joseph P. Liu, Copyright Rulemaking: Past as Prologue, 33 BERKELEY TECH. L.J. 628, 634 (2018).

77. See Karyn Temple Claggett, Meet the U.S. Copyright Office: Creativity at Work, LiBRARY OF CONGRESS (March 9, 2017), https://blogs.loc.gov/copyright/2017/03/meet-the-u-scopyright-office-creativity-at-work/ [https://perma.cc/3AU5-LZJJ] (noting that the Office has a staff of roughly 400 employees); LIBRARY OF CONGRESS, FISCAL 2018 BUDGET JUSTIFICATION 115 (2018), https://www.loc.gov/portals/static/about/reports-and-budgets/ documents/budgets/fy2018.pdf [https://perma.cc/Q5MN-6EH6] (noting that "the registration staff lost approximately 25\% (50 FTE) of its examining staff' since 2010); Email from Erik Bertin, Deputy Dir. of Registration Policy and Practice, to Aaron Perzanowski (May 10, 2018, 10:05AM) (stating that more than 150 employees work within the registration division) (on file with the author).

78. U.S. COPYRIGHT OFFICE, Fiscal 2016 ANNUAL REPORT 9 (2016), https://www.copyright.gov/reports/annual/2016/ar2016.pdf [https://perma.cc/XTL3- 
copyrightability under U.S. law, the Office does not conduct a probing analysis of each work. ${ }^{79}$ Nonetheless, it does engage in a meaningful, if understandably limited, evaluation that results in a non-trivial refusal rate. ${ }^{80}$ Many of those refusals result from the failure to satisfy one or more of the substantive requirements for copyrightability. ${ }^{81}$ So one should expect the Office to have considerable contributory expertise — gained through both formal training and longstanding experience-in applying the legislative and judicial standards for originality, subject matter, and the useful article doctrine, in addition to the formal requirements of registration. ${ }^{82}$

Under its interpretation of the statutory language and relevant precedent, the Office has long maintained that "words and short phrases ... familiar symbols or designs; mere variations of typographic ornamentation, lettering or coloring" are not subject to copyright. ${ }^{83}$ The Office has relied on that reading to refuse registrations for a variety of works. ${ }^{84}$ The en banc Third Circuit opinion in Southco v. Kanebridge, authored by then-Judge Alito, characterized the Office's approach as "reflect[ing] a 'body of experience and informed judgment to which courts and litigants may properly resort for guidance." " 85

CZHY] [hereinafter FISCAL 2016 REPORT]. That same year, the Office recorded 10,865 documents reflecting assignments, licenses, and other transactions relating to 197,000 works. And it forwarded some 635,000 deposited copies of works to the Library of Congress. Id.

79. Robert Kasunic, Copyright from Inside the Box: A View from the U.S. Copyright Office Keynote Address, 39 COLUM. J.L. \& ARTS 311, 318 (2016) ("The registration process simply examines the claim and the deposit and seeks to ensure that the legal and formal requirements of a claim in copyright are met in accordance with our longstanding institutional expertise in these questions.").

80. See id. at 315 (noting a roughly $5 \%$ refusal rate). In recent years, the refusal rate was lower. See FISCAL 2016 REPORT, supra note 78, at 9 (noting that the Office processed 469,455 applications, of which 12,656 were rejected, a rate of roughly $2.7 \%$ ).

81. See generally REVIEW BOARD LETTERS OnLINE, U.S. COPYRIGHT OFF., https://www.copyright.gov/rulings-filings/review-board/index.html [https://perma.cc/ A45X-ZV7P] (last visited Nov. 20, 2018).

82. Of course, acknowledging the Office's expertise does not mean that it always reaches the correct result with respect to particular interpretations or specific works.

83. 37 C.F.R. S 202.1(a) (2018).

84. See, e.g., Letter from Regan A. Smith, Copyright Office Review Bd., to Bryce J. Maynard (Jan. 31, 2018), https://www.copyright.gov/rulings-filings/review-board/docs/livlogo.pdf [https://perma.cc/DL6G-PU5T] (affirming the Board's refusal to register the copyright); Letter from Catherine Rowland, Copyright Office Review Bd., to B. Anna McCoy (Sept. 20, 2017), https://www.copyright.gov/rulings-filings/review-board/ docs/rub-dirt.pdf [https://perma.cc/W32X-983S] (affirming the Board's refusal to register the copyright); Letter from Regan A. Smith, Copyright Office Review Bd., to Michael L. Gentlesk, II (Aug. 23, 2016), https://www.copyright.gov/rulings-filings/review-board/docs/fuck-snowglobe.pdf [https://perma.cc/7WCX-NMEC] (affirming the Board's refusal to register the copyright).

85. Southco, Inc. v. Kanebridge Corp., 390 F.3d 276, 286 n.5 (3d Cir. 2004)). The court 
Similarly, Office regulations tracking section 102(b) of the Copyright Act exclude "ideas, plans, methods, systems, or devices, as distinguished from the particular manner in which they are expressed or described in a writing." ${ }^{86}$ This prohibition, too, has formed the basis for refusals to register. ${ }^{87}$ In 2012 , the Office issued additional guidance in the form of a policy statement clarifying that compilations comprised of otherwise ineligible systems or methods were not registrable. ${ }^{88}$ For example, the Office explained that "a compilation of yoga poses, may be precluded from registration as a functional system or process in cases where the particular movements and the order in which they are to be performed are said to result in improvements in one's health or physical or mental condition." 89 The Central District of California, confronting just such a claim, deferred to the Office's policy, citing the "specialized experience, broader investigations, and information available to [it].",90

The Office also has "considerable expertise" evaluating the separability of pictorial, graphic, and sculptural elements of useful articles. ${ }^{91}$ Such "determinations are routinely made by the Register and are unquestionably related to the substantive area of the agency's business." "92 Separability is the sort of question in which the "Office continually engages," one court to conclude that "the Copyright Office's expertise in identifying and

explained that the "Office's longstanding practice of denying registration to short phrases merits deference," although it declined to clarify the precise degree of deference warranted. Id. at 286; see also N.Y. Mercantile Exch., Inc. v. IntercontinentalExchange, Inc., 389 F. Supp. 2d 527, 543 (S.D.N.Y. 2005), aff'd 497 F.3d 109 (2d Cir. 2007) (“The Copyright Office's longstanding practice is to deny Copyright protection to words and short phrases, and courts have found that the policies and interpretation of the Office are entitled to deference."); Garcia v. Google, Inc., 786 F.3d 733, 741 (9th Cir. 2015) (crediting the Office's “expert opinion” barring "a copyright claim by an individual actor or actress in his or her performance contained within a motion picture").

86. 37 C.F.R. S 202.1(b).

87. See, e.g., Letter from Chris Weston, Copyright Office Review Bd., to Ali Fayad (May 9, 2017), https://www.copyright.gov/rulings-filings/review-board/docs/converse-flowdepths.pdf [https://perma.cc/52J3-T22K] (affirming the Board's refusal to register the copyright).

88. See Registration of Claims to Copyright, 77 Fed. Reg. 37605, (Jun. 22, 2012) (codified at 37 C.F.R. pt. 201).

89. Id. at 37607.

90. Bikram's Yoga Coll. of India, L.P. v. Evolation Yoga, LLC, 105 U.S.P.Q.2d (BNA) 1162, 1165 n.5 (C.D. Cal 2012), aff'd 803 F.3d 1032 (9th Cir. 2015).

91. Esquire, Inc. v. Ringer, 591 F.2d 796, 801 (D.C. Cir. 1978); see also Eltra Corp. v. Ringer, 579 F.2d 294, 297-98 (4th Cir.1978); Varsity Brands, Inc. v. Star Athletica, LLC, 799 F.3d 468, 480 (6th Cir. 2015), aff'd sub nom. Star Athletica, L.L.C. v. Varsity Brands, Inc., 137 S. Ct. 1002 (2017) ("The Copyright Office unquestionably has experience identifying useful articles and pictorial, graphic, and sculptural works.").

92. Norris Indust., Inc. v. Int'l. Tel. \& Tel. Corp., 696 F.2d 918, 922 (11th Cir. 1983).

93. Kieselstein-Cord v. Accessories by Pearl, Inc., 632 F.2d 989, 994 (2d Cir. 1980). 
thinking about the difference between art and function surpasses ours." 94 "The Office's approach to separability has been criticized for its inconsistency. ${ }^{95}$ But in fairness to the Office, the courts have not fared much better. ${ }^{96}$

\section{B. FORMAL REQUIREMENTS FOR REGISTRATION}

In addition to the substantive standards for copyrightability, a registration application must meet certain formal requirements. ${ }^{97}$ Beyond the statutory text, Congress granted the Office specific rulemaking authority to determine a range of issues related to registration: the administrative classes in which works should be placed; the specific deposit requirements for each class; and whether "a single registration for a group of related works" is sufficient. ${ }^{98}$ Since registration or refusal are statutory prerequisites for an infringement suit, ${ }^{99}$ courts consider whether these formal obligations have been satisfied with

94. Varsity Brands, 799 F.3d at 480; see also Mazer v. Stein, 347 U.S. 201, 214 (1954) (concluding that "as a standard we can hardly do better than the words of the present [Copyright Office] Regulation").

95. The Chief of the Examining Division at one time explained that "the office has taken almost every conceivable position" on the question. William F. PATRY, 2 PATRY ON COPYRIGHT \ 3:139.10 (2018) [hereinafter 2 PATRY ON COPYRIGHT].

96. See Star Athletica, 137 S. Ct. 1002 (holding that "an artistic feature of the design of a useful article is eligible for copyright protection if the feature (1) can be perceived as a two- or three-dimensional work of art separate from the useful article and (2) would qualify as a protectable pictorial, graphic, or sculptural work either on its own or in some other medium if imagined separately from the useful article”); Kisselstein-Cord, 632 F.2d 989 (determining that ornamental features of belt buckles were conceptually separable "sculptural elements" partly on the basis of the reactions of customers, critics, and experts); Brandir Int'l, Inc. v. Cascade Pac. Lumber Co., 834 F.2d 1142 (2d Cir. 1987) (determining that sculptural elements of a bike rack were not separable because they did not reflect "the designer's artistic judgment exercised independently of functional influences"); Carol Barnhart, Inc. v. Econ. Cover Corp., 773 F.2d 411 (2d Cir. 1985) (determining that expressive features of mannequins were not conceptually separable on the basis of an objective analysis of the work and its function); see also Masquerade Novelty, Inc. v. Unique Indus., Inc., 912 F.2d 663, 670 (3d Cir. 1990) ("Courts have twisted themselves into knots trying to create a test to effectively ascertain whether the artistic aspects of a useful article can be identified separately from and exist independently of the article's utilitarian function.”).

97. See 17 U.S.C. $₫ 409$ (2012).

98. 17 U.S.C. $\int 408(c)(1)$ (authorizing specification by regulation the administrative classes for purposes of deposit and registration); 37 C.F.R. \202.3(b)(5)-(9) (2018) (setting out requirements for group registration); see 17 U.S.C. \408(c)(2) (requiring the Office to "establish regulations specifically permitting a single registration for a group of works by the same individual author, all first published as contributions to periodicals, including newspapers ...").

99. The Supreme Court will soon decide whether registration occurs once the Office renders a decision or merely when a registration application has been submitted to the Office. See Fourth Estate Pub. Ben. Corp. v. Wall-Street.com, LLC, 138 S. Ct. 2707 (2018) (granting certiorari). 
some regularity. ${ }^{100}$ And those courts generally recognize the Office's expertise in evaluating the formal adequacy of an application.

In Alaska Stock v. Houghton Mifflin, the Ninth Circuit considered whether registration of a large number of photographs as a single collective work constituted registration of the underlying individual images. ${ }^{101}$ The collective registration omitted the names of many of the authors as well as the titles of the individual photos, which defendant Houghton Mifflin argued conflicted with the plain meaning of the statute. ${ }^{102}$ The Office's longstanding interpretation of the statute permits applications for collective works, and the component works contained therein, "even if the application does not specify the authors and titles of the component works." 103 But since the Office's position was expressed through "internal agency manuals and opinion letters," the court was bound by them "only to the extent that those interpretations have the power to persuade." 104 Nonetheless, the Office's thirty-year history of interpreting and applying the provisions of the 1976 Act, and its intimate exposure to the practical considerations collective works present convinced the court to accept the Office's approach. ${ }^{105}$ Other courts have been divided on the extent to which they are ultimately persuaded by the Office's approach to collective registration, but none have questioned the Office's unique insights into the problem, and implicit recognition of the Office's contributory expertise in making the legal determinations inherent in registration decisions. ${ }^{106}$

100. The Supreme Court has clarified that despite the statute's insistence that "no civil action for infringement ... shall be instituted" absent registration or refusal, the Supreme Court has held that $\int 411$ does not restrict a federal court's subject-matter jurisdiction involving claims of unregistered works. Reed Elsevier, Inc. v. Muchnick, 559 U.S. 154, 157, 170-71 (2010).

101. Alaska Stock, LLC v. Houghton Mifflin Harcourt Publ'g Co., 747 F.3d 673, 675 (9th Cir. 2014).

102. Id. at 679-80.

103. Id. at 677 .

104. Id. at 685; see Muench Photography Inc. v. Houghton Mifflin Harcourt Publ'g Co., 712 F. Supp. 2d 84, 91-95 (S.D.N.Y. 2010) (applying Chevron deference to regulations promulgated under $\int 408$ (c) and Skidmore deference to Office circulars and the Compendium automated database registration but said the works were not properly registered).

105. Alaska Stock, 747 F.3d at 678 (noting that "this has been the Copyright Office interpretation '[f] or more than thirty years" " and that "collective works, such as newspapers and magazines, can contain hundreds - if not thousands - of copyrightable works that the claimant owns but did not author"').

106. Compare Metro. Reg'l Info. Sys. v. Am. Home Realty Network, Inc., 722 F.3d 591, 597-99 (4th Cir. 2013) (following the Office's interpretation); Morris v. Bus. Concepts, Inc., 283 F.3d 502, 505-06 (2d Cir. 2002) (finding the Office's position persuasive), with Muench Photography, 712 F. Supp. 2d at 94 (S.D.N.Y. 2010) ("[A]sking the Court flatly to ignore the requirement that the authors' names be listed ... goes a bridge too far."); Bean v. Houghton 


\section{Administration OF STATUTORY LiCENSES}

The Copyright Act contains a variety of statutory licenses that permit specified uses of protected works so long as the user complies with the relevant formalities and pays the required royalties to copyright holders. ${ }^{107}$ Many of these provisions direct the Office to prescribe regulations for the filing of relevant documentation. ${ }^{108}$

The Office has been in the business of administering one of those statutory licenses, the mechanical license, for more than a century-since the advent of player pianos prompted Congress to include it in the Copyright Act of 1909. ${ }^{109}$ Today, the Office collects royalties under statutory licenses, including the cable, satellite, and digital audio recording licenses. ${ }^{110}$ In 2016, those royalties totaled more than $\$ 240$ million that was eventually dispersed to copyright holders. ${ }^{111}$

Rates under these and other licenses have been set by the Copyright Royalty Board (CRB), a separate division of the Library of Congress, since 2005. ${ }^{112}$ The three-judge CRB panel is designed to offer expertise in both

Mifflin Harcourt Publ'g Co., 2010 WL 3168624, at*4 (D. Ariz. Aug. 10, 2010) (holding that registrations of collective works containing photographs were insufficient to permit individual photographers to sue for infringement).

107. See, e.g., 17 U.S.C. \111(d) (2012) (providing for a statutory license for secondary transmissions by cable systems); $\int 112(\mathrm{e})$ (providing for a statutory license for ephemeral recordings); $\int 114(\mathrm{f})$ (providing for a statutory license for certain digital audio transmissions); \ 115 (providing for a statutory license to make and distribute phonorecords); \119 (providing for a statutory license for secondary transmissions by satellite carriers); $\int 122$ (providing for a statutory license for secondary transmissions of local television programming by satellite carriers); see also 17 U.S.C. S 1003(a) (requiring royalty payments for the importation and distribution of digital audio recording devices and digital audio recording media).

108. See, e.g., 17 U.S.C. S 111(d) (stating a cable system shall "deposit with the Register of Copyrights, in accordance with requirements that the Register shall prescribe by regulation . . . a statement of account ...”); \ 115(b)(1) ("Any person who wishes to obtain a compulsory license under this section shall ... serve notice of intention .... The notice shall comply, in form, content, and manner of service, with requirements that the Register of Copyrights shall prescribe by regulation.”); $\int 119$ (“A satellite carrier ... shall, on a semiannual basis, deposit with the Register of Copyrights, in accordance with requirements that the Register shall prescribe by regulation ... a statement of account.").

109. See Copyright Act of 1909 \& $1(\mathrm{e})$, Pub. L. No. 60-349, 35 Stat. 1075, 1075-76 (repealed 1976); 17 U.S.C. $\int 115$ (2012) (providing that "any other person, including those who make phonorecords or digital phonorecord deliveries, may, by complying with the provisions of this section, obtain a compulsory license to make and distribute phonorecords" of musical works that have been previously distributed to the public).

110. See FISCAL 2016 REPORT, supra note 78, at 10.

111. See id. Royalties under other statutory licenses are administered by licensing organizations like the Harry Fox Agency, for mechanical licenses, and SoundExchange, for digital performance rights.

112. See 17 U.S.C. \ 801. 
copyright law and economics. ${ }^{113}$ However, the Office retains considerable input on legal questions confronting the CRB. For any "novel material question of substantive law" the CRB must "request a decision of the Register of Copyrights, in writing." "114 The CRB can also seek the Register's input on matters of statutory interpretation or other substantive legal questions. ${ }^{115}$ And the Register has the power to review a CRB decision for legal error. ${ }^{116}$ Nonetheless, this division of labor reflects, in part, the Office's relative lack of expertise-either contributory or interactional_-in economic questions.

The Office exercises considerable administrative authority over these statutory licenses. And its interpretations of their provisions, informed by its longstanding day-to-day responsibility for them, have been recognized by courts. In perhaps the most powerful example, the Eleventh Circuit accepted the Office's interpretation of the term "cable system" under the $\int 111$ statutory license as excluding satellite providers, ${ }^{117}$ and it did so despite the fact that the Office's regulations conflicted with the court's own holding in a prior case. ${ }^{118}$ And the D.C. Circuit has noted that the "Copyright Office certainly has greater expertise in [interpreting the terms of $\ 111$ ] than do the federal courts." $" 119$

But even with respect to these statutory licenses, the Office's expertise has its limits. Although the bulk of the Office's regulatory output relates to these licenses, ${ }^{120}$ it is important to distinguish between administrative and substantive regulations. Some Office rules relate to record keeping and other procedural considerations, while others define various categories of services

113. 17 U.S.C. $\int 802$ (a) (providing that one judge must be an expert in copyright law and another in economics). Although the CRB can claim some degree of legal and economic expertise, it is far from ideally situated to set royalty rates that allocate billions of dollars annually among copyright holders and service providers. Aside from its three administrative judges, the CRB has a total staff of three. See $\int 802(\mathrm{~b})$. Although an extreme example, entrusting the regulation of billion dollar industries to a skeleton crew of federal employees is emblematic of the lack of administrative resources devoted to copyright law.

114. 17 U.S.C. $\int 802(f)(1)(B)$.

115. See 17 U.S.C. $\int 802(\mathrm{f})(1)(\mathrm{A})(\mathrm{ii})$.

116. See 17 U.S.C. $\int 802(\mathrm{f})(1)(\mathrm{D})$.

117. See 37 C.F.R. \ 201.17(k) (2018).

118. See Satellite Broad. \& Communs. Ass'n of Am. v. Oman, 17 F.3d 344, 348 (11th Cir. 1994); NBC v. Satellite Broad. Networks, Inc., 940 F.2d 1467, 1471 (11th Cir. 1991).

119. Cablevision Sys. Dev. Co. v. Motion Picture Ass'n of Am., Inc., 836 F.2d 599, 608 (D.C. Cir. 1988); see also Fox TV Stations, Inc. v. Aereokiller, LLC, 851 F.3d 1002, 1011 (9th Cir. 2017) (describing the Office as "institutionally better equipped than [the Court is] to sift through and to make sense of the vast and heterogeneous expanse that is the Act's legislative history"); Fox TV Stations, Inc. v. FilmOn X LLC, 150 F. Supp. 3d 1, 24 (D.D.C. 2015) (noting the Office's "unique expertise in this highly technical area of the law").

120. Regulations relating to these statutory licenses account for $64 \%$ of Copyright Office regulations. See Joseph P. Liu, supra note 76, at 634. 
subject to different royalty rates. ${ }^{121}$ Although the Office has a strong claim to expertise with respect to the former, it is far from clear that either the Office or the CRB have the expertise necessary to define and distinguish between various classes of digital services that are neither identified nor defined in the Copyright Act. That is properly the responsibility of Congress.

This discussion is not intended to be an exhaustive account of those areas of copyright law in which the Office can make a strong claim of expertise. Questions related to deposit, ${ }^{122}$ renewal, ${ }^{123}$ and publication ${ }^{124}$ —among others-also implicate longstanding duties that frequently require the Office's careful consideration. To generalize from these examples, the Office's expertise is clearest when it interprets statutory provisions or implements rules related to those issues it confronts on a day-to-day basis, either because of its general administrative duties or an explicit congressional mandate. In those domains, the Office primarily leverages contributory expertise gained through both formal training and repeat experience. But as the next Part will demonstrate, the Office's role has expanded well beyond its contributory expertise and likely beyond its current interactional expertise.

121. Compare 37 C.F.R. pt. 360.3 (outlining the form and content of claims), with 37 C.F.R. pt. 385 (defining rates for the use of musical works in making and distributing phonorecords for more than a dozen types of services).

122. See 37 C.F.R. S 202.19 (defining "best edition" and "complete copy" for purposes of deposit).

123. Courts have not always been receptive to the Office's views on renewal, however. See Bartok v. Boosey \& Hawkes, Inc., 523 F.2d 941, 947 n.10 (2d Cir. 1975) (refusing to defer to the Office on an issue of first impression); Broad. Music, Inc. v. Roger Miller Music, Inc., 396 F.3d 762, 778 (6th Cir. 2005) (declining to follow the Office's interpretation of renewal provisions).

124. See Batjac Prods., Inc. v. GoodTimes Home Video Corp., 160 F.3d 1223, 1230, 1235-36 (9th Cir. 1998) (embracing the Office's view that "publication of a motion picture constitutes the publication of its soundtrack"). 


\section{THE LIMITS OF THE OFFICE'S EXPERTISE}

Copyright law has grown increasingly technical as the copyright marketplace has grown increasingly technological. Driven in part by a desire for a more flexible and responsive regulatory model, the Office has been granted new rulemaking authority and has pursued new opportunities to influence policy in the digital environment. But the Office does not possess unique insight into every question confronting copyright law today. For instance, the Office is not particularly well-positioned to offer expert guidance - much less draft binding exemptions from liability_on questions at the frontier of copyright's distention into the everyday lives of digital consumers. As software permeates the market for consumer goods, copyright law increasingly collides with complex regulatory structures and policy debates that remain largely unfamiliar to the Office.

This Part focuses on the DMCA rulemaking to demonstrate that the expansion of the Office's responsibilities over the past two decades has already outstripped its current expertise. When it comes to questions like device security, privacy, competition, and public safety, the Office has no contributory expertise to speak of, and there is little reason to believe it has developed much in the way of interactional expertise.

\section{A. The DMCA Rulemaking}

Section 1201 of the DMCA prohibits the circumvention of technological protection measures that control access to copyrighted works. ${ }^{125}$ In other words, it establishes liability-distinct from traditional copyright infringement_-for bypassing, removing, or disabling a technological lock that restricts access to a copyrighted work. In response to concerns voiced by a variety of interest groups and industries, Congress included a number of narrowly tailored exemptions to $\int 1201$. These include circumvention undertaken by law enforcement ${ }^{126}$ and nonprofit libraries, ${ }^{127}$ as well as circumvention necessary for encryption research, ${ }^{128}$ security testing, ${ }^{129}$ some acts of reverse engineering, ${ }^{130}$ and the protection of personally identifiable information. ${ }^{131}$ With the exception of the broad law enforcement carveout, these exceptions are exceedingly narrow.

125. See 17 U.S.C. S 1201(a)(1)(A) (2012). It also prohibits trafficking in tools that enable the circumvention of both access and copy control. See $\iint 1201(\mathrm{a})(2),(b)(1)$.

126. See 17 U.S.C. \1201(e).

127. See 17 U.S.C. $\$ 1201(\mathrm{~d})$.

128. See 17 U.S.C. \1201(g).

129. See 17 U.S.C. \1201(j).

130. See 17 U.S.C. \ 1201(f).

131. See 17 U.S.C. \$ 1201(i). 
Recognizing the likelihood that other exceptions may prove necessary, Congress provided for a triennial rulemaking-either as a "fail-safe mechanism" "132 that would help the statute keep pace with a rapidly changing marketplace or as a deflection from political accountability for a potentially unpopular impingement on consumer rights. ${ }^{133}$ The statute calls on the Librarian of Congress, acting on the recommendation of the Register of Copyrights, ${ }^{134}$ to conduct a rulemaking in order to identify classes of copyrighted works, the noninfringing uses of which are likely to be adversely affected by the prohibition on circumvention in the succeeding three-year period. ${ }^{135}$ In practice, the Office conducts the rulemaking through a notice and comment process, building and evaluating the factual record, providing the legal analysis, and ultimately determining which exemptions should be granted. ${ }^{136}$ The statute includes five factors to be considered in evaluating exemption proposals:

(i) the availability for use of copyrighted works;

(ii) the availability for use of works for nonprofit archival, preservation, and educational purposes;

(iii) the impact ... on criticism, comment, news reporting, teaching, scholarship, or research;

(iv) the effect of circumvention ... on the market for or value of copyrighted works; and

(v) such other factors as the Librarian considers appropriate. ${ }^{137}$

Beyond this basic framework, the statute leaves the procedural and substantive contours of the rulemaking in the hands of the Librarian-and in practice, the Register. In effect, when Congress enacted the DMCA, it gave the Office a new job for which it was poorly prepared. The rulemaking, which essentially asks the Office to draft new exceptions to $\int 1201$, entails a range of

132. H.R. REP. NO. 105-551, pt. 2, at 36 (1998) (internal quotation omitted).

133. See Bill D. Herman \& Oscar H. Gandy, Jr., Catch 1201: A Legislative History and Content Analysis of the DMCA Exemption Proceedings, 24 CARDOZO ARTS \& ENT. L.J. 121, 127-28 (2006).

134. In only one instance has the Librarian of Congress declined to follow the Register's recommendation. In 2010, the Register opposed renewing an existing exemption proposed by the American Federation for the Blind that permitted circumvention of ebook DRM to enable the read-aloud function or screen readers, determining that proponents had not met their evidentiary burden under a de novo review. The Librarian "considered but rejected the Register's recommendation" and exempted such acts of circumvention. 75 Fed. Reg. 43,838 (July 27, 2010).

135. See 17 U.S.C. $\int 1201(a)(1)(C)$.

136. The statute provides that the Office "shall consult with the Assistant Secretary for Communications and Information of the Department of Commerce." Id. As a result, the National Telecommunications and Information Administration weighs in during the rulemaking process.

137. Id. 
technology-specific factual questions, inquiries into the market impact of certain behaviors by users, and determinations of noninfringing uses. Rather than leveraging the Office's expertise on matters at the heart of its day-to-day responsibilities, the DMCA rulemaking foists on the Office a set of questions it has no business answering. ${ }^{138}$ Nor does a triennial process - completed just six times over two decades ${ }^{139}$ —afford the Office any meaningful opportunity to develop the expertise necessary to discharge its statutory duties.

The history of the triennial rulemaking reveals an Office struggling mightily. The Office has applied a set of shifting and unpredictable standards that have yielded inconsistent and sometimes surprising results. In the most dramatic example, the Register's refusal to renew a twice-granted exemption permitting owners of mobile phones to remove digital locks that prevented them from lawfully using their devices on competing carrier networks led to over 100,000 signatures on a White House petition, ${ }^{140}$ an Federal Communications Commission (FCC) investigation, ${ }^{141}$ a private agreement among carriers to allow unlocking, ${ }^{142}$ and an act of Congress overturning the Register's decision. ${ }^{143}$ Although that particular determination managed to capture the public's attention, Office rulemaking generally goes unnoticed. ${ }^{144}$

138. See Herman \& Gandy, supra note 133, at 124 ("This is a significant deviation from the previous role of Copyright Office rulings, which have historically considered only technical matters, leaving interpretation of issues such as fair use to the courts.”).

139. As of this writing, the Office is in the midst of the seventh triennial rulemaking.

140. See Derek Khanna, Cellphone Unlocking Is the First Step Toward Post-SOPA Copyright Reform, BoING BoING (Feb. 22, 2013), https://boingboing.net/2013/02/22/taking-on-realreform-in-a-pos.html [https://perma.cc/SS3F-KP99].

141. See Derek Khanna, FCC to Investigate Cellphone Unlocking, ForBES (Mar. 1, 2013), https://www.forbes.com/sites/derekkhanna/2013/03/01/fcc-to-investigate-cellphoneunlocking/\#1b3aec28137b [https://perma.cc/V56B-KLHX].

142. See Roger C. Sherman \& Kris Monteith, Wireless Providers Fulfill Commitment to Let Consumers Unlock Mobile Phones, FED. COMM. COMMIssion (Feb. 11, 2015), https:// www.fcc.gov/news-events/blog/2015/02/11/wireless-providers-fulfill-commitment-letconsumers-unlock-mobile-phones [https://perma.cc/HCK8-HR7Z].

143. See Unlocking Consumer Choice and Wireless Competition Act, Pub. L. No. 113144 (2014).

144. Short of political pressure, it remains unclear how - or whether-the outcome of a $\int 1201$ rulemaking can be challenged. Since the Office follows formal notice-and-comment procedures in response to an explicit delegation of authority, courts may apply Chevron deference in evaluating the choice to grant or deny an exemption. In a recent case challenging both the failure to grant certain exemptions and the narrow scope of others, plaintiff researchers argued that the final rule was arbitrary and capricious in violation of the APA. See Complaint, Green v. Dep't of Justice, No. 1:16-cv-01492 (D.D.C. July 21, 2016). In response, the Department of Justice maintained that since the final rule was issued by the Librarian of Congress, sovereign immunity precluded any APA challenge. See Memorandum in Support of Defendants' Motion to Dismiss, Green v. Dep't of Justice, No. 1:16-cv-01492-EGS (D.D.C. Sept. 29, 2016) ("[C]ourts including the D.C. Circuit have repeatedly held that the APA's 


\section{B. Rulemaking Procedures \& StANDARds}

In implementing the DMCA rulemaking, the Office has made a number of contested interpretive choices. ${ }^{145}$ First, the directive to identify "classes of works," as opposed to classes of users or types of use, that should be exempt from the anticircumvention provision was initially interpreted quite literally by the Office. In the first two rulemakings, proposals were required to identify a section 102 class of works - like sound recordings or audiovisual works. ${ }^{146}$ Those classes could be further narrowed by additional descriptive limitations such as the media in which the works are fixed, their content, or the type of protection measures applied to them. ${ }^{147}$ But the Register categorically rejected proposals that limited the class of works by identifying groups of users or types of use of works. ${ }^{148}$

In 2006, however, the Office dramatically altered its approach. Under its new interpretation of the statute, ${ }^{149}$ limiting a class by use or user was permissible. Indeed, of the six exemptions the Office recommended, four contained user- or use-based limitations. ${ }^{150}$ This shift with respect to one of

waiver of sovereign immunity in 5 U.S.C. $\int 702$ does not apply to claims against the Library of Congress, nor can the APA's right of action in 5 U.S.C. $\int 706$ be invoked against the Library of Congress.").

145. Although styled as a rulemaking, the Office's approach is atypical. Rather than conduct independent fact finding and propose potential exemptions, the Office- - for reasons almost certainly related to limited resources and expertise-relies on "proponents" to submit exemptions proposals and build a factual record in support. "Opponents" are then given an opportunity to submit objections. And both sides of this adversarial process are heard in formal hearings before the Office. See Jonathan Band, The Complexity Dialectic: A Case Study From Copyright Law 3 (Mar. 10, 2015) (unpublished manuscript), http://infojustice.org/archives/34061 [https://perma.cc/EE3V-LUL7] ("[T] Office has converted the rulemaking into a quasi-adjudicatory proceeding, with burdens of proof, rounds of submissions, and formal hearings.").

146. The Commerce Committee Report on the DMCA explained that a class should be "a narrow and focused subset of the broad categories of works of authorship ... identified in Section 102 of the Copyright Act.” H.R. REP., supra note 132, at 38.

147. See Memorandum from Marybeth Peters, Register of Copyrights, to James H. Billington, Librarian of Cong., Recommendation of the Register of Copyrights in RM 2002-4; Rulemaking on Exemptions from Prohibition on Circumvention of Copyright Protection Systems for Access Control Technologies (Oct. 27, 2003), https://www.copyright.gov/1201/docs/registers-recommendation.pdf [https://perma.cc/ $36 \mathrm{VN}-\mathrm{E} 25 \mathrm{~F}$ ] [hereinafter 2003 Recommendation] ("[A]ttributes of the works themselves, and not by reference to some external criteria such as the intended use or users of the works.").

148. See Exemption to Prohibition on Circumvention of Copyright Protection Systems for Access Control Technologies, 65 Fed. Reg. 64,556, 64,560 (Oct. 27, 2000); 2003 Recommendation, supra note 147, at 84-85.

149. See 2003 Recommendation, supra note 147, at 17-20.

150. The use- or user-based classes included audiovisual works used by film studies professors for educational purposes, computer programs in obsolete formats used for archival 
the cornerstone principles of the rulemaking is largely responsible for the uptick in granted exemptions, but at the same time, it has led to their increasing narrowness. ${ }^{151}$

Once a class has been defined, the Office must determine whether the anticircumvention provisions are likely to interfere with noninfringing uses of works within that class. The question of infringement is typically the province of federal courts, not the Office. ${ }^{152}$ The Office has little authority or experience adjudicating infringement claims, so determining whether the uses envisioned by exemption proposals are noninfringing presents a challenge: Infringement is often a complex, fact intensive question, not a matter of simply interpreting the statute. Indeed, the statute offers precious little guidance on the question, ${ }^{153}$ as evidenced by the competing approaches to infringement adopted among, and sometimes within, the circuit courts. The uses at issue in the rulemaking often involve new technologies and untested infringement theories, exacerbating the challenge facing the Office.

Fair use complicates things even more. Initially the Office, cognizant of its own limitations, approved exemptions only for uses that were unquestionably noninfringing as a matter of well-settled law. ${ }^{154}$ But such a conservative approach threatened to render the rulemaking useless. Over time, the Office grew bolder. In 2006, the Office recommended an exemption for audiovisual works when circumvention is undertaken to enable educational use by university professors on the uncontested assumption that such use was fair. ${ }^{155}$

purposes, wireless phone firmware used for to lawfully connect to a wireless network, and sound recordings for the purposes of testing, investigating, or correcting security flaws. See Memorandum from Marybeth Peters, Register of Copyrights, to James H. Billington, Librarian of Cong., Recommendation of the Register of Copyrights in RM 2005-11; Rulemaking on Exemptions from Prohibition on Circumvention of Copyright Protection Systems for Access Control Technologies 1-2 (Nov. 17, 2006), https://www.copyright.gov/1201/docs/ 1201_recommendation.pdf [https://perma.cc/U4PE-LZ74] [hereinafter 2006 Recommendation].

151. In one instance, it led to the Register narrowing a previously-granted exemption. See Christopher Moseng, The Failures and Possible Redemption of the DMCA Anticircumvention Rulemaking Provision, 12 J. TECH. L. \& POL'Y 333, 350 (2007) (describing the narrowed exemption for "certain computer programs and video games"); see also Mark Gray, New Rules for a New Decade: Improving the Copyright Office's Anti-Circumvention Rulemakings, 29 BERKELEY TECH. L.J. 759, 792 (2014) (describing an exemption for DVDs as a "dense, four-paragraph block of single-spaced text that took over two pages to spell out").

152. Some have suggested that the primary function of the rulemaking is "reducing the role of the courts — and of fair use - in the digital millennium." Herman \& Gandy, supra note 133 , at 124.

153. See generally 17 U.S.C. S 501 (2012).

154. See 2003 Recommendation, supra note 147, at 155.

155. See 2006 Recommendation, supra note 150, at 1. 
In $2010,{ }^{156}$ the Office went further, engaging in a full analysis of the four fair use factors in connection with proposals to exempt jail-breaking mobile phones and security testing on video games. ${ }^{157}$ These determinations were not based on any directly-applicable judicial precedent, but the Office's own application of the fair use factors. ${ }^{158}$ Regardless of whether it reached the appropriate result, assuming the authority to make fair use determinations signals a considerable expansion of the Office's role. The Office continued to analyze fair use in subsequent rulemakings, but has emphasized existing precedent rather than its own judgment where possible. ${ }^{159}$

The Office's struggle here is perhaps best understood as a function of expertise. The Office has precious little experience deciding questions of infringement or independently analyzing fair use. Although it lacks any contributory expertise, the Office does, however, have a strong working knowledge of the statute and case law, suggesting that it may be able to bring interactional expertise to bear on these questions. The Office seems to recognize that fair use determinations are at the outer edge of its expertise and

156. The third triennial rulemaking was significantly delayed; the Register made her recommendations to the Librarian in June of 2010, some ten months after exemptions granted in 2006 were set to expire.

157. Memorandum from Marybeth Peters, Register of Copyrights, to James H. Billington, Librarian of Cong., Recommendation of the Register of Copyrights in RM 2008-8; Rulemaking on Exemptions from Prohibition on Circumvention of Copyright Protection Systems for Access Control Technologies 92-100, 183-203 (June 11, 2010), https:/ /www.copyright.gov/1201/2010/initialed-registers-recommendation-june-11-

2010.pdf [https://perma.cc/9YKC-AX4T] [hereinafter 2010 Recommendation].

158. Arielle Singh, Note, Agency Regulation in Copyright Law: Rulemaking Under the DMCA and Its Broader Implications, 26 BERKELEY TECH. L.J. 527, 563 (2011) ("The Register showed that she did not have to rely on judicial precedent or direct statutory language to determine if a use was noninfringing.").

159. In 2012, the Office determined that the creation of noncommercial videos, documentary films, and multimedia ebook, and educational uses of audiovisual works were "likely to be fair uses." Memorandum from Marybeth Peters, Register of Copyrights, to James H. Billington, Librarian of Cong., Recommendation of the Register of Copyrights, Section 1201 Rulemaking: Fifth Triennial Proceeding to Determine Exemptions to the Prohibition on Circumvention 126-27, (Oct. 12, 2012), https://www.copyright.gov/1201/2012/ Section_1201_Rulemaking_2012_Recommendation.pdf [https://perma.cc/EDR6-VB2C] [hereinafter 2012 Recommendation]. And in 2015, the Office concluded space-shifting and format-shifting of ebooks and audiovisual works were likely not fair. But that making e-books accessible to blind, visually impaired, or print disabled persons, mobile phone unlocking, modifying smart television firmware to enable interoperability were likely fair. See Memorandum from Marybeth Peters, Register of Copyrights, to James H. Billington, Librarian of Cong., Recommendation of the Register of Copyrights, Section 1201 Rulemaking: Sixth Triennial Proceeding to Determine Exemptions to the Prohibition on Circumvention 132 (Oct. 8, 2015), https://www.copyright.gov/1201/2015/registers-recommendation.pdf [https://perma.cc/Q92L-BEPB] [hereinafter 2015 Recommendation]. 
has taken a reasonably cautious approach when confronted with such arguments by carefully analogizing to existing judicial precedent. Problematically, by creating a new venue for the resolution of fair use questions growing out of technological protection measures, the rulemaking is reducing the likelihood that courts will hear the current generation of fair use cases, shifting power from the courts to the Office and impeding the development of fair use to address new circumstances. ${ }^{160}$

One other change in the Office's rulemaking standards is noteworthy. In each subsequent rulemaking, the Office has reviewed existing exemptions de novo, insisting on a new showing of ongoing harm. ${ }^{161}$ This approach has proven problematic for a number of reasons. Proposing an exemption and building the factual record to support it is a massive undertaking. So de novo review places a significant burden on the individuals and non-profit organizations that submit the vast majority of exemption proposals. ${ }^{162}$ This approach places a similar undue burden on the Office itself, which must deploy resources to re-litigate issues even when no facts have changed. ${ }^{163}$ The de novo review standard also ignores the ways in which the existence of an exemption may reduce the availability of facts, demonstrating harm to noninfringing use in subsequent periods. ${ }^{164}$

For the seventh triennial rulemaking, the Office announced a new process

160. Herman \& Gandy, supra note 133, at 188; Elec. Frontier Found., DMCA Triennial Rulemaking: Failing the Digital Consumer at 6 (Dec. 1, 2005), https://www.eff.org/document/ dmca-triennial-rulemaking-failing-digital-consumer [https://perma.cc/4VFR-WWM4] ("Rather than treating fair use as a forward-looking, evolving regime, the Copyright Office has made it backward-looking, effectively barring courts from addressing the fair use implications of new digital consumer technologies in the 21st century.”).

161. See generally 2003 Recommendation, supra note 147; 2006 Recommendation, supra note 150; 2010 Recommendation, supra note 157; 2012 Recommendation, supra note 159; 2015 Recommendation, supra note 159.

162. Proponents of exemption proposals report dedicating over 500 hours of time to build the legal and factual case for an exemption. See U.S. COPYRIGHT OFFICE, SECTION 1201 of Title 17: A RePORT OF THE REgister OF COPYRIGHTS 128 (June 2017), https://www.copyright.gov/policy/1201/section-1201-full-report.pdf

[https://perma.cc/M2QD-THC7] [hereinafter SECTION 1201 REPORT]; see also Band, supra note 145 , at 5 ("The triennial rulemaking has evolved into a complex undertaking that is difficult, if not impossible, for individuals or entities to navigate successfully without retaining counsel.").

163. See Moseng, supra note 151, at 353 (noting that the existing exemption for website blacklists was denied in 2006 "not because of affirmative changes in the marketplace . . but because the party seeking the exemption chose to rest on the record from three years ago, and argued that nothing had changed") (internal quotation omitted).

164. See generally Aaron Perzanowski, Evolving Standards \& the Future of DMCA Anticircumvention Rulemaking, 10 J. INTERNET L. 1 (2007) (noting problems posed by the de novo standard). 
for considering exemption renewals. ${ }^{165}$ Under this streamlined process,

a party must provide a short paragraph explaining the basis for its request to readopt the exemption and declare that: if the exemption is not renewed, users would be unable to make noninfringing uses of the copyrighted works, and are likely to rely upon the exemption in the next three-year period; and there has been no material change in the facts ....166

In the absence of "meaningful opposition," the Office will recommend the exemption "on existing evidence." 167 For the reasons outlined above, this is an important and positive reform to the rulemaking process. The optimistic could interpret it as a sign that the Office is making slow incremental improvements in the rulemaking. But it also shows that twenty years into the triennial rulemaking, the Office continues to shift the goalposts. However, these shifting standards do not represent the strongest critique of the Office's role in the triennial rulemaking.

\section{Rulemaking Subject MatTer \& Expertise}

With each round, the subject matter of the proposed exemptions has moved farther afield from the Office's expertise. ${ }^{168}$ Exemption proposals commonly raise contested questions of fact and law regarding software and a host of other new technologies. These questions entail matters of law and policy far beyond copyright law-from election security and consumer privacy to environmental protection and patients' rights. The Office-designed to create and track records of copyright claims_-cannot be expected to resolve those matters through the application of genuine expertise absent a ground-up rethinking of its size, structure, and mission.

Since 2006, the Office has been repeatedly required to tackle matters that it was never designed to and should have never been tasked with addressing. The questions-orthogonal to the Office's expertise, but central to the rulemaking-arise in three distinct contexts. First, to determine whether exemption proposals identify significant harms, the Office considers impacts of protection measures that extend well beyond mere access to copyrighted works. Second, to the extent the Office considers fair use, as it increasingly has, as the basis for a finding of non-infringement, the nature and character of

165. See generally Rulemaking Proceedings Under Section 1201 of Title 17, U.S. COPYRIGHT OFFICE, https://www.copyright.gov/1201/ [https://perma.cc/55KQ-XPG7].

166. See Transcript of Informational Video on Rulemaking, U.S. Copyright Office, Streamlined Petitions for Renewed Exemptions (2018), https://www.copyright.gov/1201/ 1201_streamlined_renewal_transcript.pdf [https://perma.cc/GVT9-HVS2].

167. Id.

168. See Ohm \& Reid, supra note 9, at 1683-86. 
the use compels the Office to consider the broader social value of acts, like security testing and medical diagnostics, enabled by circumvention. And third, the fifth catch-all factor, under which the Office considers "such other factors as the Librarian considers appropriate," has been used by the Office to import considerations well outside the scope of copyright law, including wireless competition and vehicle safety. ${ }^{169}$

\section{Security Testing}

Beginning in 2006, the Office has recommended a series of exemptions related to security testing that illustrate well the degree to which the $\int 1201$ rulemaking tests the limits of the Office's expertise. The first such exemption was prompted by Sony BMG's distribution of music CDs that surreptitiously installed protection measures cloaked by a rootkit that caused serious security vulnerabilities for millions of consumers. ${ }^{170}$ In order to clarify the legality of research to uncover and address security flaws in Digital Rights Management (DRM) technologies, two academic researchers sought an exemption. ${ }^{171}$

As the Office noted at the time, "[i]t is difficult to fit concerns about computer security into a rulemaking process which is focused on noninfringing uses of copyrighted works." ${ }^{, 172}$ Factually, the proposal required the Office to engage deeply with the operation of these protection measures, the risks they create for users, and the research methods used to assess them. Moreover, it forced the Office to consider implications of the anticircumvention rule well beyond the availability and market value of copyrighted works. The Office was obliged to take into account "the strong public interest in preventing the distribution of software that poses security risks to the computers of unwitting consumers." ${ }^{173}$

In 2010, the Office approved a similar exemption-this time applied to video games that pose potential security risks. In assessing the risk of harm, the Office was asked to consider the proponent's claim that the security risks at issue were "much more dangerous than the Sony rootkit flaw" and opponents' contention that "the vulnerability ... was resolved and a patch made available to consumers." ${ }^{174}$ Even a charitable interpretation of the Office's expertise must admit that it is poorly positioned to determine whether

169. 17 U.S.C. \1201(a)(1)(C)(v) (2012).

170. See generally Deirdre K. Mulligan \& Aaron K. Perzanowski, The Magnificence of the Disaster: Reconstructing the Sony BMG Rootkit Incident, 22 BERKELEY TECH. L.J. 1157, 1158 (2007).

171. In the interest of disclosure, as a law student under the supervision of Deirdre Mulligan, I represented Ed Felten and Alex Halderman in the rulemaking, drafted their exemption proposal, and testified in support of it.

172. 2006 Recommendation, supra note 150, at 60.

173. $I d$.

174. 2010 Recommendation, supra note 157, at 180-81 (internal quotation omitted). 
security risks are best addressed through independent research or marketfocused self-discipline.

By 2015, similar security concerns had spread to a range of products including voting machines, medical devices, cars and other land vehicles, and consumer devices generally. ${ }^{175}$ Perhaps more than any others, these proposals exemplify the problem the Office now faces in \$ 1201 rulemaking. Exemption opponents argue that "the risk to public safety that would be created by granting [it] outweighs the minimal benefits offered by unauthorized security research." 176 How an Office designed to register copyright claims is meant to answer that question with anything approaching expertise remains a mystery. ${ }^{177}$

Not only must the Office evaluate a factual record that ranges from hacking voice messaging systems in children's toys, automobile remote locks, vote tallies, and pacemakers, but it must also take the maze of regulations and guidance issued by other federal agencies into account. ${ }^{178}$ In 2015 , the Office informed the Department of Transportation (DOT), the Environmental Protection Agency (EPA), and the Food and Drug Administration (FDA) of the rulemaking. ${ }^{179}$ Each of those agencies cautioned against the proposed exemption. "FDA expressed concerns about the proposed exemptions . . . for medical device software security research"; "EPA urged the Office to decline to recommend the proposed exemption ... for vehicle software security research [because it might] slow or reverse gains under the Clean Air Act"; and "DOT noted concerns over the nature and timing of the potential public disclosure of security research." 180

As DOT's position suggests, one of the key questions the Office wrestled with was "the extent to which any exemption should incorporate a requirement that flaws uncovered by security researchers be disclosed to the software developer and/or product manufacturer before being communicated

175. See 2015 Recommendation, supra note 159, at 7.

176. Id. at 292 .

177. In a letter to the Office, the NTIA recognized the difficulty. Noting the "extensive discussion of matters with no or at best a very tenuous nexus to copyright protection," NTIA urged the Office to avoid "interpreting the statute in a way that would require it to develop expertise in every area of policy that participants may cite on the record." Letter from Lawrence E. Strickling, Assistant Sec'y. for Commc'ns \& Info. \& Adm'r of Nat'l Telecomm. \& Info. Admin., to Maria A. Pallante, Register of Copyrights 3-4 (Sept. 18, 2015), https://copyright.gov/1201/2015/2015_NTIA_Letter.pdf [https://perma.cc/3YVLKV3G].

178. See id.

179. See USCO Letters to Other Agencies, U.S. COPYRIGHT OFF., https://www.copyright.gov/1201/2015/USCO-letters/ [https://perma.cc/Q692-UU6Y] (last visited Nov. 20, 2018).

180. 2015 Recommendation, supra note 159, at 313-14. 
to the public at large." 181 This is, simply put, a question the Office is not qualified to answer. The Office summed up the problem it faces well:

The rules that should govern such research hardly seem the province of copyright, since the considerations of how safely to encourage such investigation are fairly far afield from copyright's core purpose of promoting the creation and dissemination of creative works. Rather, the rules that should govern are best considered by those responsible for our national security and for regulating the consumer products and services at issue. That said, it is inescapable that the anticircumvention prohibition in section 1201(a)(1) plays a role in the debate. ${ }^{182}$

\section{Unlocking}

In 2006, the Office recommended an exemption for circumvention of protection measures on wireless telephone firmware to enable users to connect to a mobile network, a process commonly referred to as unlocking. As the Office correctly explained, these protection measures are "used by wireless carriers to limit the ability of subscribers to switch to other carriers, a business decision that has nothing whatsoever to do with the interests protected by copyright." 183 As a result, they implicate questions of competition in the wireless market, typically the province of the Federal Communications Commission (FCC). ${ }^{184}$

The Office effectively renewed that exemption in 2010, but noted that "the issues discussed herein are particularly complicated because of the mobile phone technologies at issue and the business models used in the wireless industry," a set of questions understandably outside the Office's expertise. ${ }^{185}$ The Office was called on by proponents of the exemption to consider a number of additional factors including: competition; small business development; communications law; environmental concerns; and existing subsidy arrangements. ${ }^{186}$ As the Office noted, these "may be valid arguments to make before other administrative agencies, such as the FCC, but are inapt here, in a proceeding conducted by the Copyright Office and the Librarian of Congress, which have no responsibilities for, and no particular expertise in, such matters ...."187 What the Office failed to recognize, however, is that there is no avoiding these questions for an agency tasked with ongoing

\footnotetext{
181. Id. at 275 .

182. Id. at 316 .

183. 2006 Recommendation, supra note 150 , at 52.

184. See 47 U.S.C. $\int 332$ (2012).

185. 2010 Recommendation, supra note 157, at 107.

186. See generally id.

187. Id. at 153 .
} 
stewardship of $\int 1201$ exemptions. ${ }^{188}$

In what was perhaps an effort to retreat from this unfamiliar territory, the Office in 2012 all but eliminated the unlocking exemption, recommending a provision limiting the exemption to phones "acquired within ninety days of its effective date." "189 Although the Office continued to assert that at least some unlocking was non-infringing, "the Register conclude[d] that ... there are ample alternatives to circumvention - that is, the marketplace has evolved such that there is now a wide array of unlocked phone options available to consumers." 190

The backlash to the new rule was swift and severe. Over 100,000 people signed a White House petition to overrule the Office. ${ }^{191}$ After FCC commissioners spoke out against the decision, ${ }^{192}$ the National Telecommunications and Information Administration (NTIA) successfully petitioned the FCC to take on the issue. ${ }^{193}$ Shortly thereafter, the industry announced a set of voluntary principles to facilitate unlocking. Moreover, Congress passed legislation to revert to the broader 2010 exemption. ${ }^{194}$ After this rebuke, the Office expanded the unlocking exemption in 2015 to include not only mobile phones but also, tablets, portable connectivity devices like hotspots, and wearable devices like smartwatches. ${ }^{195}$

188. As the NTIA has noted "non-copyright concerns have been relevant to proposed exemptions in past rulemakings, highlighting in particular the competition and telecommunications policies supporting past cellphone unlocking exemptions." 2015 Recommendation, supra note 159 , at 245.

189. 2012 Recommendation, supra note 159, at 100.

190. Id. at 95 .

191. The Obama administration expressed its disagreement with the decision, but appeared unwilling or unable to directly challenge it. Edward Wyatt, F.C.C. Backs Consumers in Unlocking of Cellphones, N.Y. TIMES (Mar. 4, 2013), https://www.nytimes.com/2013/ 03/05/technology/fcc-urges-a-right-to-unlock-cellphones.html [https://perma.cc/2KJARXDQ] ("Because the Library of Congress, and therefore the copyright office, are part of the legislative branch, the White House cannot simply overturn the current ruling.").

192.

I think that is one powerful librarian. I also think this new approach does not make sense. Because if you have a mobile device, want to unlock it, and you are not bound by a service contract-you should be able to use it on another network. That makes our markets for wireless service more competitive - and that benefits consumers.

Jessica Rosenworcel, Comm'r, Fed. Commc'n Comm'n, Statement Re: Cell Phone Unlocking Presentation (Dec. 12, 2013).

193. See Khanna, supra note 141.

194. See Unlocking Consumer Choice and Wireless Competition Act, Pub. L. No. 113144 (2014).

195. See 2015 Recommendation, supra note 159, at 6-7. 


\section{Jailbreaking}

Relatedly, the Office recommended an exemption in 2010 that permitted circumvention of software on mobile phones for the purpose of enabling interoperability with other programs. ${ }^{196}$ This process, commonly known as jailbreaking, allows users to install software that has not been approved by the phone's manufacturer of the developer of its operating system. ${ }^{197}$

In opposition to this proposal, Apple argued that its protection measures were necessary to avoid a host of calamities that included: "crashes and instability;" "malfunctioning and safety;" "invasion of privacy;" "exposing children to age-inappropriate content;" "viruses and malware;" and "the inability to update software." 198 As a result, Apple argued that an exemption would reduce the value of its software. While the Office ultimately rejected those arguments, the challenges demonstrate the degree to which the rulemaking calls on the Office to consider questions far beyond its expertise. In 2012, the Office followed a similar analysis and recommended a similar exemption. ${ }^{199}$ And in 2015, it expanded the exemption to include "smartphones and portable all-purpose mobile computing devices . . .."200

It also recommended the adoption of a new, but related exemption for smart televisions. ${ }^{201}$ There, LG raised similar arguments that an exemption "would harm 'platform security' by making smart TVs more vulnerable to malicious software or hacking." 202 Ultimately, the Office found that claim unpersuasive, but that determination - right or wrong-is not rooted in the unique perspective of an expert agency.

\section{Additional 2015 Exemptions}

The Office recommended three additional exemptions in 2015 that illustrate the expanding scope of the technologies under consideration in the rulemaking and underscore how far the Office has been required to stray from its core responsibilities.

First, the Office endorsed an exemption for circumventing protection measures applied to computer programs that control the functioning of motorized land vehicles, excluding their telematics or entertainment systems. ${ }^{203}$ Access to that software is often necessary to diagnose problems, perform

196. See 2010 Recommendation, supra note 157, at 100.

197. Id.

198. Id. at 80.

199. See generally 2012 Recommendation, supra note 159.

200. 2015 Recommendation, supra note 159, at 192.

201. See id. at 217.

202. Id. at 209 .

203. See id. at 246. 
routine maintenance, install replacement parts, repair malfunctions, and modify a vehicle. ${ }^{204}$ But manufacturers from General Motors to John Deere have restricted access to the code that operates these vehicles. ${ }^{205}$ As a result, "vehicle owners must take their cars to authorized repair shops, or purchase expensive manufacturer-authorized tools, to diagnose and repair their vehicles." 206 Such tactics could reduce competition in the market for repair services and replacement parts, undermine safety, and reduce the resale value of vehicles. ${ }^{207}$ Though deeply troubling, it's worth remembering that none of these harms bear any plausible connection to copyright law.

Opponents of the exemption raised concerns related to public safety, security, and the environment. They claimed the exemption could reduce vehicle fuel efficiency, increase emissions, ${ }^{208}$ and threaten cybersecurity. Perhaps most astoundingly, they argued an exemption "would make it easier for violent partners and predators to monitor, stalk, and harm victims through access to what is now protected internal automobile systems and technology." ${ }^{209}$ And again, both DOT and EPA weighed in against the exemption. While the Office took these concerns into account, finding that "the fifth statutory factor ... weigh[s] against an exemption," it ultimately recommended it. ${ }^{210}$ Even for those who agree that the exemption was warranted, the mismatch between the Office's expertise and the considerations it was forced to weigh is striking.

Second, the Office recommended an exemption that would permit circumvention necessary for operators of $3 \mathrm{D}$ printers to use the material, or feedstock, of their choice. ${ }^{211}$ In much the same way that Lexmark and other printer makers have attempted to control toner cartridges, 3D printer manufacturers have attempted to leverage their power over durable goods to

204. Aaron Perzanowski \& Jason Schultz, The End of Ownership: Personal Property IN THE Digital ECONOMY 146-47 (Laura DeNardis \& Michael Zimmer eds., 2016).

205. See 2015 Recommendation, supra note 159, at 228.

206. Id. at 224 .

207. Some farmers have been forced to download firmware for their equipment from Ukrainian websites due to the restrictions imposed by John Deere. See Jason Koebler, Why American Farmers Are Hacking Their Tractors with Ukrainian Firmware, MOTHERBOARD (Mar. 21, 2017), https://motherboard.vice.com/en_us/article/xykkkd/why-american-farmers-arehacking-their-tractors-with-ukrainian-firmware [https://perma.cc/GV4X-NRNJ].

208. Ironically, the anticircumvention provision itself contributed to Volkswagen's ability to hide its efforts to cheat emissions testing protocols for its diesel vehicles. See PERZANOwSKI \& SCHULTZ, supra note 204.

209. 2015 Recommendation, supra note 159, at 233.

210. Id. at 244 .

211. See id. at 356. 
control the market for consumables. ${ }^{212}$

Proponents of the exemption argued that it would "strengthen property rights, encourage competition and innovation, and meet consumer expectations concerning ownership of consumer devices." 213 Although the Office signaled its agreement, the FDA expressed concern that the exemption could "create unintended public health and safety risks in relation to medical devices produced using 3D printers." ${ }^{214}$ The Office acknowledged that although those concerns were "not copyright-related," they were "sufficiently weighty to merit consideration in drafting an exemption." 215 As a result, the Office included the proviso that "the exemption shall not extend to ... goods or materials for use in commerce the physical production of which is subject to legal or regulatory oversight ...."216

Finally, the Office recommended an exemption permitting circumvention to enable access to "data generated by implanted medical devices." 217 Pacemakers, defibrillators, insulin pumps, and other implanted devices record and communicate medical data to hospitals and doctors' offices. Because of encryption and other protection measures, patients are often unable to easily and quickly access data about their own bodies. ${ }^{218}$

Device makers and the FDA, which offered recent guidance recommending such protection measures, expressed misgivings related to device security and patient privacy. ${ }^{219}$ Although proponents of the exemption argued that "the Librarian and the Office are ill equipped[sic] to make determinations about privacy and patient safety," the Office determined that the "serious nature of these concerns means that they must be carefully considered ...."220 In the end, the Office was convinced that the case in favor of the exemption outweighed the concerns of the FDA. ${ }^{221}$

In addition to renewals of existing exemptions, the 2018 rulemaking has generated new or expanded proposals for exemptions related to jailbreaking, unlocking, device repair, security research, 3D printing, and avionics. ${ }^{222}$ For

212. See Lexmark Int'l, Inc. v. Static Control Components, Inc., 387 F.3d 522, 545 (6th Cir. 2004); Impression Prod., Inc. v. Lexmark Int'l, Inc., 137 S. Ct. 1523, 1530 (2017).

213. 2015 Recommendation, supra note 159 , at 362.

214. Id. at 375 .

215. Id.

216. Id. at 377.

217. Id. at 7.

218. PERZANOWSKI \& SCHULTZ, supra note 204 at 152-53.

219. See 2015 Recommendation, supra note 159, at 22-23.

220. Id. at $388,399$.

221. See id. at 399

222. Section 1201 Exemptions to Probibition Against Circumvention of Technological Measures Protecting Copyrighted Works: Petitions for Newly Proposed Exemptions, U.S. COPYRIGHT OFF., 
the foreseeable future, the Office will face the unenviable but statutorilyrequired task of resolving a set of questions it should never have been asked in the first place. Even when the Office reaches the right result, one should remain mindful of the strain on and the distraction to the Office the rulemaking represents.

In many respects, the Office deserves considerable credit for its handling of the rulemaking process, not because of its deep expertise but because of its absence. With a congressional mandate that stacks the odds against it, the Office has muddled through the immense triennial undertaking and, with a few notable exceptions aside, has managed to reach an appropriate or at least defensible result more often than not. However, whether any one commentator agrees with these outcomes is quite distinct from the question of the Office's expertise and the wisdom of entrusting this process to its ambivalent care. Indeed, regardless of what decisions the Office ultimately makes with respect to these exemption proposals, the record makes clear that the Office is all but guaranteed to face matters beyond any reasonable definition of its expertise.

These concerns over the mismatch between the Office's expertise and the technological and policy questions presented by the spread of software extend beyond the $\int 1201$ rulemaking. In 2015, for example, Senators Grassley and Leahy - noting that "copyrighted software is ... now essential to the operation of our refrigerators, our cars, our farm equipment, our wireless phones, and virtually any other device you can think of' —asked the Office to provide guidance on software's "ever-increasing role in defining consumer interactions with devices and products ...." 223 In response, the Office conducted a study — soliciting comments, holding roundtables_and ultimately issued its analysis of a range of issues that included the resale of software-enabled consumer products, their repair and modification, security, interoperability, and competition. ${ }^{224}$ While many of these issues implicate copyright doctrine, the Office is no better positioned to address their practical, technological, and economic complexities in a report to Congress than it is in the context of a

https://www.copyright.gov/1201/2018/petitions-091317 [https://perma.cc/TW23-LSUP] (last visited Nov. 20, 2018).

223. See Letter from Charles Grassley, Chairman, Comm. on the Judiciary, \& Patrick Leahy, Ranking Member, Comm. on the Judiciary, to Maria Pallante, Register of Copyrights (Oct. 22, 2015), https://www.grassley.senate.gov/sites/default/files/judiciary/upload/201510-22\%20GEG-Leahy $\% 20$ to $\% 20$ Copyright $\% 20$ Office $\% 20 \% 28$ Software $\% 20$ Copyright $\%$ 20 Study $\% 20$ Request $\% 29$.pdf [https://perma.cc/2PBW-ENGZ].

224. See CONSUmer Products RePORT, supra note 7, at 27-60. The Office's 69-page report ultimately concluded that "faithful application of existing copyright law doctrines should provide no barrier to legitimate uses." Id. at ii. 
rulemaking. ${ }^{225}$ Despite the poor fit between the modern copyright environment and the expertise of the Office, questions of this sort will only grow more common and more pressing in years to come. So it is important to consider what, if anything, the Office can do to build the sort of expertise these obligations demand.

\section{AN EXPERT COPYRIGHT OFFICE}

The current mismatch between the Office's expertise and its duties risks distracting the Office from its core responsibilities. Moreover, it undermines the Office's determinations in the DMCA rulemaking and other regulatory efforts, and it threatens to skew the input Congress receives as part of the legislative process. As an initial matter, both Congress and the Office should approach any new delegations of authority with caution, and they should consider ways to better align the Office's existing authority with its expertise. Moving forward, if the Office is expected to function as an expert agency, Congress should direct and fund the creation of new centers of expertise within it. Finally, as copyright continues to encroach on the everyday lives of citizens, the Office should establish an internal consumer advocate to ensure the public interest is taken into account.

\section{A. Refocusing THE OfFicE'S AgENDA}

In light of the foregoing discussion, proposals to shift additional authority from the courts and Congress to the Office should be met with skepticism. Recent years have seen suggestions for the Office to adjudicate small claims, ${ }^{226}$ resolve fair use disputes, ${ }^{227}$ and craft exemptions to traditional infringement liability. ${ }^{228}$ But the Office is poorly positioned to take on these additional

225. More generally, Congress sometimes asks the Office to study important questions of copyright law and policy. See, e.g., U.S. Copyright OfFICE, FEDERAL Copyright PROTECTION FOR PRE-1972 SOUND RECORDINGS: A REPORT OF THE REgISTER OF Copyrights (2011); U.S. Copyright OfFice, DMCA SECTION 104 RePort: A REPORT OF the Register of Copyrights Pursuant to \ 104 of the Digital Millennium COPYRIGHT ACT (2001). The input Congress receives from the Office would be more useful and reliable if informed by greater technical and economic expertise. As for the courts, they should continue to follow the Office's guidance only to the extent they find it persuasive.

226. See generally H.R. 5757, 114 ${ }^{\text {th }}$ Cong. (2d Sess. 2016).

227. See Michael W. Carroll, Fixing Fair Use, 85 N.C. L. REv. 1087, 1127-28 (2007) (proposing the creation of a Fair Use Board within the Office, but noting that "deference to the agency's expertise would be inappropriate in these circumstances" and "the power to make generally binding interpretations of the law would remain with the federal courts").

228. See Liu, supra note 74, at 152 ("Congress could delegate to the Copyright Office the authority to promulgate additional exemptions via regulation.”). See also Terry Hart, Copyright Reform Step Zero, 19 INFO. \& COMM. TECH. L. 147, 152 (2010) (suggesting that "detailed provisions and exceptions which currently pad Title 17 would be shifted to the C.F.R., where 
obligations. ${ }^{229}$ It lacks the necessary expertise and resources. Although it continues to make progresses, the Office is struggling to hoist its registration and recordation systems into the twenty-first century.

Rather than expanding the Office's portfolio, Congress should consider scaling back its duties. The DMCA rulemaking is an obvious place to start. Short of repealing $\int 1201$ altogether-an option that has considerable merit beyond lessening the burdens facing the Office ${ }^{230}$ - there are a number of steps worth considering. Informed in part by the Office's prior rulemaking efforts, Congress should significantly expand the existing statutory exemptions for reverse engineering, security testing, and encryption research. ${ }^{231}$ Moreover, Congress should consider crafting new permanent statutory exemptions. Those might address specific concerns, like repair and unlocking, that have emerged since the DMCA's enactment. ${ }^{232}$ Or more broadly, Congress could exempt circumvention that lacks any nexus with infringement ${ }^{233}$ or circumvention undertaken by the owner of a device or copy. ${ }^{234}$ After twenty years, the unintended consequences of $\int 1201$ have become abundantly clear to anyone paying attention. ${ }^{235}$ Rather than force the Office to plug new holes in the dike every three years, Congress should take responsibility for the over breadth of the anticircumvention rules.

In the absence of congressional intervention, the Office could relieve some of its own burden by granting broader temporary exemptions, subject to a presumption of renewal, rather than the narrowly-defined, parsimonious exemptions it has granted in recent rulemakings. ${ }^{236}$ Another approach that would at least partially extricate the Office from the burden of resolving questions beyond its expertise is to determine that certain activities simply do

they could be more effectively administered and reformed as needed").

229. Liu, supra note 74, at 157 ("The Copyright Office currently does not have sufficient resources or expertise to take on a substantially more robust policymaking role.”).

230. See PERZANOWSKI \& SCHULTZ, supra note 204.

231. The Office itself has recommended that Congress broaden existing statutory exemptions and create some new ones, a solution that would lessen, though not eliminate, the burden the Office faces in the rulemaking. See SECTION 1201 REPORT, supra note 162, at 6263.

232. Id. at 88-99.

233. See generally Chamberlain Group, Inc. v. Skylink Techs., Inc., 381 F.3d 1178 (Fed. Cir. 2004) (holding that a claim for circumvention requires a "critical nexus" to copyright infringement).

234. See PERZANOWSKI \& SCHUlTZ, supra note 204, at 177 (recommending an exemption for copy and device owners).

235. See generally Elec. Frontier Found., Unintended Consequences: SiXTEen YEARS UNDER THE DMCA (2014); Jacqueline Lipton, The Law of Unintended Consequences: The Digital Millennium Copyright Act and Interoperability, 62 WASH. \& LEE L. REV. 487 (2005).

236. See supra note 151 and accompanying text. 
not violate the anticircumvention provision in the first place. If consumers and researchers face a cloud of uncertain liability, the Office could provide some reassurance and clarity that security research or device unlocking, for example, do not violate $\int 1201$. So far, the Office has been reluctant to adopt that approach, opting to craft narrow temporary exemptions out of an abundance of caution. ${ }^{237}$ But the power to determine whether or not an activity presents a prima facie case of circumvention is implicit in the Office's rulemaking authority. ${ }^{238}$ When exemptions are necessary, the Office would do well to confine its analysis to those facts directly relevant to questions of circumvention and infringement. The DOT or FDA may have their own views on the advisability of technological controls, but those views are almost certainly based on non-copyright rationales. Taking those views into account will almost inevitably require the Office to exceed its expertise.

\section{B. BUILDING EXPERTISE}

Although an Office more focused on its core responsibilities is likely the best short-term solution, the Office can and should develop new expertise given the changes copyright law has undergone and will continue to confront. Even if the Office significantly narrows the factual scope of the $\ 1201$ rulemaking, its other administrative and policy responsibilities would benefit from greater expertise. As others have suggested, the Office would do well to establish internal sources of contributory expertise with respect to both economics and technology. ${ }^{239}$ While individual members of the Office staff and leadership may bring relevant experience to bear, those fortuitous personnel choices are no substitute for a long-term institutional commitment to economic and technological expertise. ${ }^{240}$

To build these capacities, the Office should name a "Chief Economist" and "Chief Technologist." ${ }^{241}$ Other federal agencies that confront similarly complex legal and policy matters have recognized the need for highly qualified experts to inform their decision making. The Federal Trade Commission

237. See generally 2006 Recommendation, supra note 150; 2010 Recommendation, supra note 157; 2012 Recommendation, supra note 159.

238. See 17 U.S.C. \ 1201(a)(1)(C) (2012).

239. Pamela Samuelson, The Copyright Principles Project: Directions for Reform, 25 BERKELEY TECH. L.J. 1175, 1205 (2010); Liu, supra note 74, at 157 (noting that "the Office would benefit from greater technological expertise" and that "increased economic expertise would be vital").

240. Former Copyright Office General Counsel Sarang Damle, for example, had a background in software development, which no doubt helped inform the Office's understanding of some software-related questions. See Abioye Ella Mosheim, An Interview with Sy Damle: General Counsel and Associate Register of the US Copyright Office, 10 LANDSLIDE (2017) https://www.americanbar.org/content/dam/aba/publications/landslide/2017-nov-dec/ interview-sy-damle.authcheckdam.pdf [https:/ / perma.cc/466J-7NG6].

241. Samuelson, supra note 239, at 1205. 
(FTC), for example, named Ed Felten its first Chief Technologist in 2011. ${ }^{242}$ Since then a series of distinguished technologists has served in that role. ${ }^{243}$ The FTC's Bureau of Economics also houses a sizable team of experts. ${ }^{244}$ The United States Patent and Trademark Office (USPTO) named Stu Graham as its first Chief Economist in 2010, ${ }^{245}$ and today that office houses four economic experts. ${ }^{246}$ The FCC has employed a Chief Economist since the $1940 s,{ }^{247}$ and it recently voted to establish an Office of Economics \& Analytics to concentrate its economics and data operations. ${ }^{248}$ The Commission also relies on a Chief Technology Officer, who advises the "the Chairman on technology and engineering issues, together with the Office of Engineering and Technology." 249

Establishing similar centers of expertise within the Office could prove beneficial in a number of ways. Deep technical expertise would not only help the Office evaluate empirical claims in the record of its rulemakings and studies, it would also better inform the Office as to what questions need to be asked in the first place. When the Office recently created its Copyright

242. See FTC Chief Technologists, FED. TRADE COMMISsIOn, https://www.ftc.gov/about$\mathrm{ftc} /$ biographies/ftc-chief-technologist [https://perma.cc/527W-86MA] (last visited Nov. 21, 2018). Felten, who sought an exemption for his research in the 2006 DMCA rulemaking, was later named Deputy U.S. Chief Technology Officer by President Obama. Megan Smith \& Alexander MacGillivray, The White House Names Dr. Ed Felten as Deputy U.S. Chief Technology Officer, White HOUSE PRESIDENT BARACK OBAMA (May 11, 2015), https://obamawhitehouse.archives.gov/blog/2015/05/11/white-house-names-dr-ed-feltendeputy-us-chief-technology-officer [https://perma.cc/9HGT-EMZB].

243. See FTC Chief Technologists, supra note 242 (listing Dr. Steve Bellovin, Dr. Latanya Sweeney, Ashkan Soltani, Dr. Laurie Faith Cranor, and Neil Chilson as Dr. Felen's successors).

244. See Burean of Economics Biographies, FED. Trade Commission, https://www.ftc.gov/about-ftc/bureaus-offices/bureau-economics/biographies [https://perma.cc/WV64-6YF4].

245. See Press Release, U.S. Patent and Trademark Office, USPTO Chief Economist Unveils Agency's New Economic Research Agenda During Conference on Intellectual Property and the Innovation Economy (Dec. 9, 2010), https://www.uspto.gov/aboutus/news-updates/uspto-chief-economist-unveils-agencys-new-economic-research-agendaduring [https://perma.cc/GR76-SKYN].

246. Economic Researchers, U.S. PATENT AND TRADEMARK OfFICE, https://www.uspto.gov/learning-and-resources/ip-policy/economic-research/economicresearchers [https://perma.cc/RV6P-K9KV] (last visited Nov. 21, 2018).

247. See Bill Melody, Dallas Smythe: A Lifetime at the Frontier of Communications, 17 CANADIAN J. Comm. (1992), https://www.cjc-online.ca/index.php/journal/article/view/693/599 [https://perma.cc/24M5-FX4M] (noting that Smythe was the FCC's first Chief Economist and served from 1943 to 1948).

248. See Order, In re Establishment of the Office of Economics and Analytics, FCC 18-7 (MD Docket No. 18-3) (Jan. 31, 2018, FCC Rcd.).

249. Chief Technology Officer of the FCC, FED. COMM. COMMISSION, https://www.fcc.gov/strategic-planning-policy-analysis/chief-technology-officer-fcc\#blockmenu-block [https://perma.cc/73TZ-LNLS]. 
Modernization Office and named its first Director of Copyright Modernization, it acknowledged the need to bolster its technological expertise when it comes to its IT infrastructure. ${ }^{250}$ The Office should apply a similar degree of self-reflection to its policy and rulemaking functions. Likewise, given the fundamentally economic justification for U.S. copyright law, the absence of expert economic analysis within the Office is both puzzling and troubling. The Office should not only have the capacity to meaningfully evaluate the economic claims of the parties before it, but it should be capable of generating independent and objective economic analysis to inform and support its policymaking. If the Office wants to grow into an agency with authority on par with the FCC or USPTO, it needs to develop a similar degree of expertise.

\section{A Voice For the Public}

To the extent increased expertise enables the Office to expand its substantive copyright policy agenda, it should consider a more formal and intentional mechanism for taking the public interest into account in its decision making. Procedurally, the Office has been careful in its rulemakings and policy studies to include a range of voices and perspectives. But the Office influences policy through non-public processes as well.

To take one recent example, the Office weighed in on the FCC's "Unlock the Box" initiative, a proposed rule that would have required cable providers to open their platforms to third-party set-top boxes. ${ }^{251}$ That rule would have enabled consumers to access licensed video content using the device of their choice, ending abusive practices by cable companies that enjoy an effective monopoly over set-top box hardware. ${ }^{252}$ In closed-door communications with the FCC, as well as a letter to certain congressional Representatives, the Office asserted that the rule would have encroached on copyright holders' "exclusive right to license" and their "right to manage the exploitation of a copyrighted work." ${ }^{253}$ Neither of those purported rights has any basis in copyright law. ${ }^{254}$ In fact, a viewer's use of a third-party cable box rather than one provided by the local cable franchise does not implicate any of the exclusive rights granted

250. See Press Release, U.S. Copyright Office, U.S. Copyright Office Announces New Division: The Copyright Modernization Office (Mar. 30, 2018), https:// www.copyright.gov/newsnet/2018/711.html [https://perma.cc/J36D-LV9G].

251. See Tom Wheeler, Chairman, Fed. Commc'ns Comm'n, Statement: FCC Proposes to "Unlock the Box" (Feb. 18, 2016), https://www.fcc.gov/document/fcc-proposes-unlockbox/wheeler-statement [https://perma.cc/D4KN-UQF7].

252. See id.

253. Letter from Maria Pallante, Register of Copyrights, to Reps. Blackburn, Butterfield, Collins, and Deutch 7 (Aug. 3, 2016).

254. See 17 U.S.C. $\int 106$ (2012). 
to copyright holders. ${ }^{255}$ Had the Office taken the public interest into account, it may have offered a more sound analysis. Instead, its view was apparently shaped by months of private phone calls and meetings with the Motion Picture Association of America, Viacom, and Comcast. ${ }^{256}$

Even when the Office does hear from the public, structural biases tend to favor the perspective of rights holders. In an interview with the American Bar Association, former Register Pallante revealed her fundamental misunderstanding of our copyright system and the Office's role within it. As she put it, "Copyright is for the author first and the nation second." ${ }^{, 57}$ While it would be a mistake to attribute this constitutionally flawed view to the Office as a whole, it is suggestive of the Office's long-recognized tendency to prioritize the interests of copyright holders over those of the public. ${ }^{258}$

In some ways, this tendency is understandable. The Office regularly interacts with copyright holders in its day-to-day operations, and rights holders and their various trade associations and industry groups are regular, repeat participants in every policy process the Office undertakes. Moreover, it is not uncommon for Office personnel to represent those same interests before and after their government service, reinforcing the ties between the Office and industry. ${ }^{259}$ More broadly, copyright policymaking faces familiar challenges when it comes to fully accounting for the public interest. While rights holders are a concentrated, organized, and sophisticated constituency, the public interest is diffuse, largely unorganized, and poorly resourced. ${ }^{200}$ Although recent years have seen certain technology firms serve as an effective counterbalance to the copyright industries, those firms are often, at best, an imperfect proxy for the interests of consumers.

To account for its biases and better reflect the interests of consumers, the

255. See Letter from Copyright Professors to Marlene Dortch, Sec'y, Fed. Commc'ns Comm'n (Sept. 22, 2016).

256. Ernesto Falcon, Newly-Released Documents Show Hollywood Influenced the Copyright Office's Comments on Set-Top Boxes, ElEc. Frontier FOund. (Oct. 25, 2016), https://www.eff.org/deeplinks/2016/10/ newly-released-documents-show-hollywoodinfluenced-copyright-offices-comments-set [https://perma.cc/T8H6-MWYJ].

257. Mike Masnick, How Can You Be Register Of Copyrights If You Don't Even Understand Copyright's Most Basic Purpose?, TECHDIRT (April 5, 2012), https://www.tech dirt.com/articles/20120330/09445718303/how-can-you-be-register-copyrights-if-you-donteven-understand-copyrights-most-basic-purpose.shtml [https://perma.cc/C4B3-WGFC].

258. Jessica Litman, Digital Copyright 74 (2001) ("Unfortunately, the Copyright Office has tended to view copyright owners as its real constituency."); Liu, supra note 74, at 158 ("One common critique of the Copyright Office has been the extent to which it has largely backed the interests of copyright holders over the interests of consumers more generally.").

259. See Rose, Clough \& PANJWAni, supra note 58, at 5-6.

260. See Jessica Litman, The Exclusive Right to Read, 13 CARdozo ArTs \& ENT. L.J. 29, 33 (1994). 
Office should consider establishing a public advocate. State and federal agencies ranging from the FDA, ${ }^{261}$ public utilities commissions, ${ }^{262}$ and insurance regulators ${ }^{263}$ have recognized that the public interest requires not only access to regulatory processes, but a concerted effort to level a playing field that, for a variety of structural reasons, tends to favor industry. A copyright public advocate would consider the impact of proposed regulations and policy positions on consumers, proactively defending the public interest as part of the Office's internal deliberative process and counterbalancing the persistent influence of industry. Such an advocate would not eliminate the need for broad participation in rulemaking and policy studies, but could help ensure that the Office gives due consideration to the impact of copyright law on the public. Further, it would lend the Office additional credibility and legitimacy.

\section{CONCLUSION}

The expertise of the Office has failed to keep pace with its expanded role in our copyright system. When it comes to a number of pressing questions of law and policy, the Office lacks the technological and economic expertise necessary to justify congressional delegations of authority and judicial deference. But the responsibility for that mismatch falls squarely on the shoulders of Congress. Rather than bear the burden of taming the monster it created in $\$ 1201$, Congress foisted that job on the Office. To address these concerns, the Office should focus its efforts on its primary registration-related responsibilities for the time being. But given its statutory duties and the chorus calling for even greater responsibility - some of which come from within the Office itself ${ }^{264}$ - the Office should also begin to build out its expertise, and Congress should provide it with the resources to do so.

261. See About the FDA Patient Representative Program, U.S. FoOd \& Drug ADMIN., https://www.fda.gov/ForPatients/About/ucm412709.htm [https://perma.cc/K7BCJYYK] (last visited Nov. 21, 2018).

262. CAL. Pub. UTIL. CODE \309.5(a) (Deering 2018), (creating an "independent Office of Ratepayer Advocates to represent and advocate on behalf of the interests of public utility customers and subscribers"); see also OFFICE OF THE OHIO CONSUMERS' COUNSEL, http://www.occ.ohio.gov/message.shtml [https://perma.cc/VRQ3-RUEZ].

263. See, e.g., The Office of the Consumer Advocate Division, W. VA. OFFs. OF THE INS. COMMISSIONER, http://www.wvinsurance.gov/Divisions/Consumer-Advocate [https:// perma.cc/7V25-VYNY] ("The Consumer Advocate is mandated to advocate for, and protect, the interest of the West Virginia consumers.").

264. See U.S. Copyright Office, Copyright Small Claims: A Report of the REGISTER OF COPYRIGHTS (2013), https://www.copyright.gov/docs/smallclaims/uscosmallcopyrightclaims.pdf [https://perma.cc/BJ7P-FVU7]. 